\title{
Combustion Characteristics for Turbulent Prevaporized Premixed Flame Using Commercial Light Diesel and Kerosene Fuels
}

\author{
Mohamed S. Shehata, ${ }^{1}$ Mohamed M. ElKotb, ${ }^{2}$ and Hindawi Salem ${ }^{2}$ \\ ${ }^{1}$ Mechanical Engineering Department, Faculty of Engineering, King Khalid University, Abha 61413, Saudi Arabia \\ ${ }^{2}$ Mechanical Power Engineering Department, Faculty of Engineering, Cairo University, University Street, Giza 12316, Egypt \\ Correspondence should be addressed to Mohamed S. Shehata; m3ohamed4@yahoo.com
}

Received 9 February 2014; Revised 2 May 2014; Accepted 2 May 2014; Published 1 June 2014

Academic Editor: Yiguang Ju

Copyright (c) 2014 Mohamed S. Shehata et al. This is an open access article distributed under the Creative Commons Attribution License, which permits unrestricted use, distribution, and reproduction in any medium, provided the original work is properly cited.

\begin{abstract}
Experimental study has been carried out for investigating fuel type, fuel blends, equivalence ratio, Reynolds number, inlet mixture temperature, and holes diameter of perforated plate affecting combustion process for turbulent prevaporized premixed air flames for different operating conditions. $\mathrm{CO}_{2}, \mathrm{CO}, \mathrm{H}_{2}, \mathrm{~N}_{2}, \mathrm{C}_{3} \mathrm{H}_{8}, \mathrm{C}_{2} \mathrm{H}_{6}, \mathrm{C}_{2} \mathrm{H}_{4}$, flame temperature, and gas flow velocity are measured along flame axis for different operating conditions. Gas chromatographic (GC) and $\mathrm{CO} / \mathrm{CO}_{2}$ infrared gas analyzer are used for measuring different species. Temperature is measured using thermocouple technique. Gas flow velocity is measured using pitot tube technique. The effect of kerosene percentage on concentration, flame temperature, and gas flow velocity is not linearly dependent. Correlations for adiabatic flame temperature for diesel and kerosene-air flames are obtained as function of mixture strength, fuel type, and inlet mixture temperature. Effect of equivalence ratio on combustion process for light diesel-air flame is greater than for kerosene-air flame. Flame temperature increases with increased Reynolds number for different operating conditions. Effect of Reynolds number on combustion process for light diesel flame is greater than for kerosene flame and also for rich flame is greater than for lean flame. The present work contributes to design and development of lean prevaporized premixed (LPP) gas turbine combustors.
\end{abstract}

\section{Introduction}

Turbulent premixed flames exhibit phenomena not found in other turbulent flows. It is natural to suppose that a premixed flame is strongly influenced by the turbulence into which it is propagating. In some circumstances, a thin flame sheet forms a connected but highly wrinkled surface that separates the reactants from the products. The environmental aspect becomes always more important for the development of energetic formation of the pollutants in the combustion chamber and consequently their emissions. Many researches are focused on new concepts for ultralow emissions combustors for gas turbine, with developments in fuel preparation and wall cooling techniques. A possible technological solution for the reduction of pollution is the use of lean prevaporized premixed (LPP) technology. Nevertheless, this new emergent technology is affected by many problems that must be solved in order to make it reliable for commercial engines. El Bakali et al. [1] studied premixed natural gas flames at stoichiometric and pressure of $10.6 \mathrm{kPa}$. Mole fraction profiles of stable species and temperature were measured using molecular beam/mass spectrometry gas chromatography and thermocouple technique. They also studied the experimental results obtained from a jet-stirred reactor at atmospheric pressure and variable equivalence ratios $(\Phi=0.75,1.0,1.5)$ for oxidation of methane/ethane mixture using natural gas. Combustion of natural gas generates low level of unwanted pollutants. In addition, economic aspect of natural gas combustion is attractive. Therefore, natural gas constitutes a serious alternative to conventional liquid fuel because of its high octane number. The recent studies show that the addition of natural gas to diesel fuel reduces pollutants in the exhaust gas. The details of these studies can be found in Papagiannakis and Hountals [2]. El-Sherif [3] studied the 
effect of minor alkanes on the combustion of premixed flames using natural gas as a fuel. The authors reported a significant effect of initial ethane concentration on the peaks of $\mathrm{CO}$ and NO. In jet stirred reactor conditions, Tan et al. [4] measured mole fraction profiles for oxidation of methane/ethane and methane/ethane/propane mixtures under a wide range of operating conditions (101.3-1013 kPa, 800-1400 K). The results showed that methane/ethane/propane is the best model fuel to represent natural gas under these conditions. Mole fraction profiles of stable, atomic, and radical species are obtained by coupling molecular beam/mass spectrometry with gas chromatography analyses. Analysis of premixed turbulent combustion includes both effects of combustion on turbulence and effects of turbulence on chemical reaction rate which is still under investigation. Chen and Ihme [5] developed and applied a combustion model for prediction of partially premixed combustion process in turbulent reacting flows. Large-eddy simulation (LES) is employed to describe the turbulent reacting flow field. The combustion process in the three-stream burner configurations is modeled using a flamelet combustion model in which details of reaction chemistry are represented in terms of set scalar quantities. Simulation results for temperature and major products species show good agreement with the experimental data. Author noticed that the scalar boundary conditions significantly affect the mixture composition in the burner. Sadanandan et al. [6] studied combustion behavior of natural gas flames with $\mathrm{H}_{2}$ as an admixture. Author used an optically accessible combustor which operates under gas turbine relevant conditions. Author investigated the influence of various parameters like mixture composition, degree of premixing, and velocity on the pollutant emissions. The results showed that the degree of premixing and the recirculation rate of burned gases play an important role on $\mathrm{NO}_{X}$ and $\mathrm{CO}$ emissions. The degree of premixing and jet velocity for optimum combustion should lead to a recirculation and mixing rates such that ignition delay is long enough to promote mixing of the fresh fuel/air with the burned gases before the flame but short enough to ensure the flame stability. At the same time, combustor residence time should be short in order to reduce the thermal $\mathrm{NO}_{X}$ formation but long enough to enable complete combustion. Obodeh and Isaac [7] investigated performance characteristics of diesel engine fuelled with diesel/kerosene blends. Pressure data for 30\% kerosene blend were higher than that for $40 \%$ kerosene blend from about 80 degrees after top dead center. The exhaust gas temperature at $100 \%$ rated load was $16.7 \%$ higher at $30 \%$ kerosene blend as compared with that obtained with diesel fuel. Brake power increased with rated load for all the fuel blends. The brake power at $100 \%$ rated load was $19.8 \%$ higher at $30 \%$ kerosene blend than that obtained when the engine was run on diesel fuel. Specific fuel consumption at $100 \%$ rated load was $7.5 \%$ lower at $30 \%$ kerosene blend than that obtained when compared with diesel fuel. It was deduced that the use of $30 \%$ kerosene along with diesel fuel will result in $10 \%$ saving on fuel cost. The several studies by Ghormade and Deshpande [8] and Kumar Reddy [9] have been done by using different vegetable oil blends with kerosene to improve the performance of a small type high speed diesel engine under high load conditions. They worked with four blends $(20 \%, 40 \%, 60 \%$, and $80 \%$ by volume) of soybean oil with kerosene as well as rapeseed oil with kerosene and compared the results with those of pure diesel fuel. They also studied the spray distribution of each blend in atmosphere using four whole nozzle injectors. The result showed that a blend of $20 \%$ vegetable oil with $80 \%$ kerosene by volume fairly improves the thermal efficiency of the test engine under high load. They were recommended to use $20 \%$ to $40 \%$ vegetable oil blends as a successful alternative fuel. Spray characteristics were studied both under high and low pressure injection in atmosphere where the low pressure injection showed better performance, Kumar Reddy [9]. Azad et al. [10] carried out experimental comprehensive study of DI diesel engine performance using biodiesel from mustard oil blends with kerosene. The vegetable oil without transesterification reaction has been blended with kerosene fuel by volume in some percentage like M20, M30, M40, and M50. Several engine parameters like brake specific fuel consumption, brake power, break mean effective pressure, exhaust gas temperature, lube oil temperature, sound level, and so forth have been determined. A comparison has been made for diesel engine performance of different biodiesel blends with kerosene. Authors recommended that it can be possible to run diesel engine with mustard and kerosene fuels blends without any modification of the engine. Poovannan and Kalivarathan [11] studied combustion process through designing two combustion chambers for lean premixed (LP) for gaseous and lean premixed prevaporized (LPP) for liquid fuels. Authors measured nitric oxides $\left(\mathrm{NO}_{X}\right)$, unburned hydrocarbons (UHC), carbon monoxide (CO), particulate matter (PM), and smoke. The design is verified using numerical analysis tools. Reasonable agreement between predictions from the preliminary design and numerical analysis is achieved which indicated that the design procedures are developed successfully. Gollahalli et al. [12] studied effects of turbulence on combustion characteristics of blends canola methyl ester (CME) and diesel fuel in a partially premixed flame environment. The experiments are conducted with mixtures of prevaporized fuel and air at an initial equivalence ratio of 7 and three Reynolds numbers of 2700,3600 , and 4500 . Three blends with 25,50 , and $75 \%$ volume concentration of CME are studied. The soot volume fraction is the highest for the pure diesel flame and did not change significantly with Reynolds number due to the mutually compensating effect of increasing carbon input rate and increasing interned air with increased Reynolds number. The global $\mathrm{NO}_{X}$ emission index is the highest and the $\mathrm{CO}$ emission index is the lowest for pure CME flame and varied nonmonotonically with biofuel percentage in the blends. The mean temperature and $\mathrm{NO}_{X}$ concentrations at threequarter flame height are generally correlated, indicating that the thermal mechanism of $\mathrm{NO}_{X}$ formation is dominant in the turbulent biofuel flames. The measurements indicate that the combustion characteristics of the turbulent flames of $\mathrm{CME} /$ diesel blends cannot predict accurately based on the blend ratio and properties of pure CME and diesel flames. Details of radical concentrations are required to understand the formation of $\mathrm{CO}$ and $\mathrm{NO}_{X}$ in the flames of blended fuels. 
The pollutants coming out from premixed flames as a result of combustion have negative impact on the global environment and consequently human health. Therefore, controlling the combustion process is essential to reduce pollutants emissions. In the present study, the combustion phenomena and flow field for prevaporized premixed flame are analyzed experimentally. The basic principle of these phenomena is that the fuel is prepared and ready for combustion due to fuel vaporization and complete mixing with air. This research is basically applied to study the combustion phenomena of commercial fuels mainly light diesel, kerosene fuels, and their blends to acquire a fundamental understanding of the combustion process and flow field for gas turbine combustor.

\section{Experimental Setup}

Experimental work is carried out at Mechanical Engineering Department, Faculty of engineering, Cairo University, Egypt. The analysis of data is carried out at Mechanical Engineering Department, Faculty of Engineering, King Khalid University, Saudi Arabia. The experimental setup is shown in Figure 1. It consists of a flat flame grid burner, fuel injector, mixing chamber, and two $7 \mathrm{~kW}$ electrical heaters. Preheated air is used to create hot flat flame without entrained air. Water cooled stainless steel isokinetic sampling probe with outer diameter $9 \mathrm{~mm}$ is used to suck samples of gases at different locations through flame axis and radius to define species concentrations for different operating conditions. Sample probe is connected to gas chromatograph (GC) detector through heated line provided by sampling valve and heater controller. Burner is designed to improve mixing of fuel and air to improve flame stability by (1) using three perforated plates located at bottom of the burner at burner throttle area and at burner exit. The three perforated plates are used as flame holder to prevent flame flash back and also to generate turbulence, (2) inserting stainless steel balls between upper and medial perforated plates to improve mixing of fuel and air. The burner converges to the middle plate and then diverges to plate of flame holder for many reasons: (1) it improves mixing of fuel and air and (2) improves flame stability by increasing the stability of the flame lift-off height and increases the size of the recirculation zone. A recirculation zone behind the perforated plate provides conditions favorable for flame holding, for example, lower velocities, heat recycling to the flame stabilizing region, and enhanced mixing of fuel/air and hot product of combustion. The recirculation zone has a temperature gradient because of the cold air flow surrounding the burner tube. Liquid fuel is sprayed into mixing tube where preheated air is required for combustion. Fuel is vaporized and mixed with air before entering into combustion space through perforated plate which is used as a flame holder. Complete vaporization of mixture at burner exit is tested to ensure that all fuel is presented in gaseous phase. Also, concentrations are measured at burner exit without combustion using $\mathrm{CO} / \mathrm{CO}_{2}$ analyzer to check low temperature reactions. The results indicated that no low temperature reactions occurred inside mixing tube or burner. The residence time for reacting mixture from point of fuel injection in mixing tube to exit from burner tip is nearly $1-2 \mathrm{~ms}$ for different operating conditions. Two base fuels are light diesel and kerosene fuels and three blends are studied. Blend $\mathrm{A}_{1}$ (75\% light diesel + 25\% kerosene), blend $\mathrm{A}_{2}(50 \%$ light diesel $+50 \%$ kerosene), and blend $\mathrm{A}_{3}$ (25\% light diesel $+75 \%$ kerosene) are also studied. According to Egyptian International Research Center, the physical and chemical properties of Egyptian diesel and kerosene fuels are listed in Table 1. From chemical formula of diesel and kerosene fuels stoichiometric fuel/air ratios are determined. For blending fuels, stoichiometric fuel/air ratios are determined according to the percentage of diesel and kerosene presented in the blend. From measuring fuel and air flow rates with calculating stoichiometric fuel/air ratios, the equivalence ratios $(\Phi)$ are determined for different operating conditions. Gas chromatograph Parker Elmer model Sigma 300 with data acquisition system model LCI-100 are used for gas analysis using two-column Poropak Q 1/8 in $\times 6 \mathrm{ft}$. and Poropak R 1/8 in $\times 8 \mathrm{ft}$. connected in series. Gas chromatograph is equipped with constant volume gas sampling valve to control volume of the sample. An infrared $\mathrm{CO} / \mathrm{CO}_{2}$ analyzer is also used for measuring $\mathrm{CO}$ and $\mathrm{CO}_{2}$. A Pt/Pt-13\% Rh thermocouple and water cooled pitot tube are used for flame temperature and gas velocity measurements. Concentrations, flame temperature, and gas velocity are measured at different locations along flame axis. Optimum condition for gas chromatography analysis, no entrained air along the flame, and flame flatness are determined and checked before measurements, Elkotb et al. [13]. Holes diameter of the perforated plate have been changed during experiments keeping air/fuel ratio and mean inlet flow velocity constant. Three hole diameters of 3.7, 2.5, and $2 \mathrm{~mm}$ have been chosen for changing the solidity ratios (blocked area/total area) to $S_{1}=0.4786, S_{2}=0.719$, and $S_{3}=0.876$. The solidity ratio is calculated as follows:

$$
\text { The solidity ratio } \begin{aligned}
(S) & =\frac{\text { Blockae area }}{\text { Total area }} \\
& =\frac{\text { Total Area }-\sum \text { Holes area }}{\text { Total area }} \\
& =1-n\left(\frac{d}{D}\right)^{2} .
\end{aligned}
$$

Each perforated plate has diameter of $38 \mathrm{~mm}$ and $5 \mathrm{~mm}$ thickness. It is provided with 55 holes of $5 \mathrm{~mm}$ center-tocenter distance. Pressure loss across the flame stabilizer is a function of the created turbulent energy and the injected fuel into the flow. Turbulence also influences the thickness of the premixed turbulent reaction zone. The recirculation zone size is nearly close to the perforated plate diameter. The central hole will give an annular recirculation zone rotating outward and the baffle will give a central recirculation zone rotating inward.

Equivalence ratio, inlet Reynolds number, and inlet mixture temperature are also studied. The inlet mixture temperature is kept constant at $673 \mathrm{~K}$ for light diesel and blends $A_{1}$ and $A_{2}$ while for kerosene and blend $A_{3}$ it is kept at $603 \mathrm{~K}$ during study effect of fuel type, fuel blends, equivalence ratio, and Reynolds number. During study effect of Reynolds number and inlet mixture temperature, the solidity ratio and equivalence ratio are kept constant. Although the used 

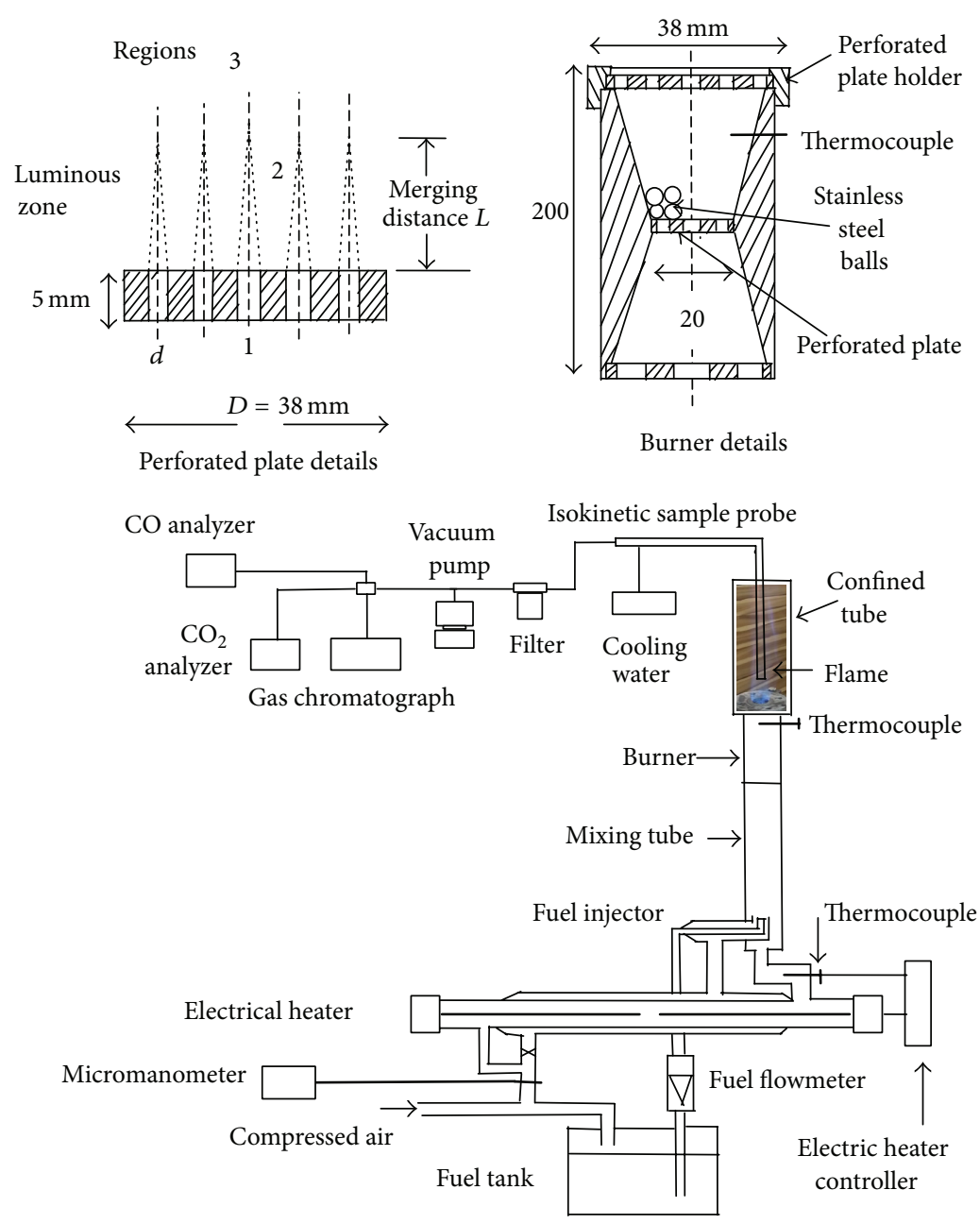

FIGURE 1: Experimental setup.

technique in this study is useful for turbulent premixed air flames, it can be generalized for other systems (gas turbines, rockets and spark ignition engines, etc.), where coupling between chemical reaction resulting from combustion and turbulent flow process exists. The aim of present work is to study effect of different operating parameters as fuel type (light diesel, kerosene fuels, and their blends), equivalence ratio, inlet Reynolds number, inlet mixture temperature, and perforated plate holes diameter on combustion process for turbulent prevaporized premixed air flames.

\section{Results and Discussions}

3.1. Concentrations, Flame Temperature, and Flow Velocity. Concentration, flame temperature, and gas flow velocity for light diesel-air flames are shown in Figure 2. In the main reaction zone, $\mathrm{CO}_{2}$ formation rate increases with increased flame temperature. In postflame zone, $\mathrm{CO}_{2}$ formation rate increases to the flame end due to decomposition of heavy fuel into light hydrocarbon that rapidly oxidizes to $\mathrm{CO}$ and $\mathrm{CO}_{2}$. Maximum $\mathrm{CO}_{2}$ concentration appeared at the flame end. In the postflame zone the high formation rate of $\mathrm{CO}_{2}$ relative to the main reaction zone attribute to heat dissipation to surrounding is not significant due to confined tube around flame. Near flame end, flame temperature drops due to complete combustion, and equilibrium condition lead to increase $\mathrm{CO}_{2}$ concentration. The formation of $\mathrm{CO}_{2}$ from $\mathrm{CO}$ and $\mathrm{O}_{2}$ as well as decomposition is kinetically limited and sensitive to high temperature due to high activation energy. Near burner tip, high $\mathrm{CO}_{2}$ concentration attributes to the hot probe tip that influences rate of reaction. In the main reaction zone $\mathrm{CO}$ formation rate is significantly higher than in the postflame zone. The maximum formation rate of $\mathrm{CO}$ appears at the early stage of combustion where hydrogen and free carbons atoms are found. $\mathrm{CO}$ concentration expects to increase at the expense of $\mathrm{CO}_{2}$ due to reaction $\mathrm{C}+\mathrm{CO}_{2} \longleftrightarrow 2 \mathrm{CO}$ in the region of low $\mathrm{CO}_{2}$ formation rate with high flame temperature and consumption of all oxygen atoms. CO concentration exceeded equilibrium concentration for many reasons Howe et al. [14] (1) CO which burns out slowly in the flame itself, (2) separation by molecular diffusion, and (3) the maximum emission of $\mathrm{C}$, $\mathrm{CH}$, and $\mathrm{OH}$, localizing in the middle of the oxidation zone. In the postflame zone $\mathrm{CO}$ concentration begins to decrease due to (1) consumption of all oxygen and fuel, (2) equilibrium 


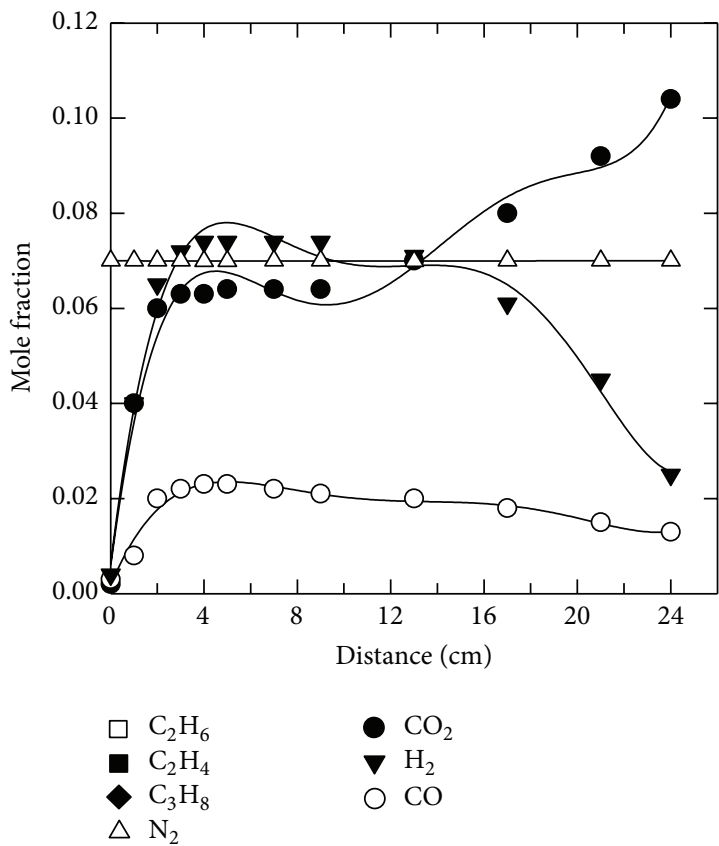

(a)

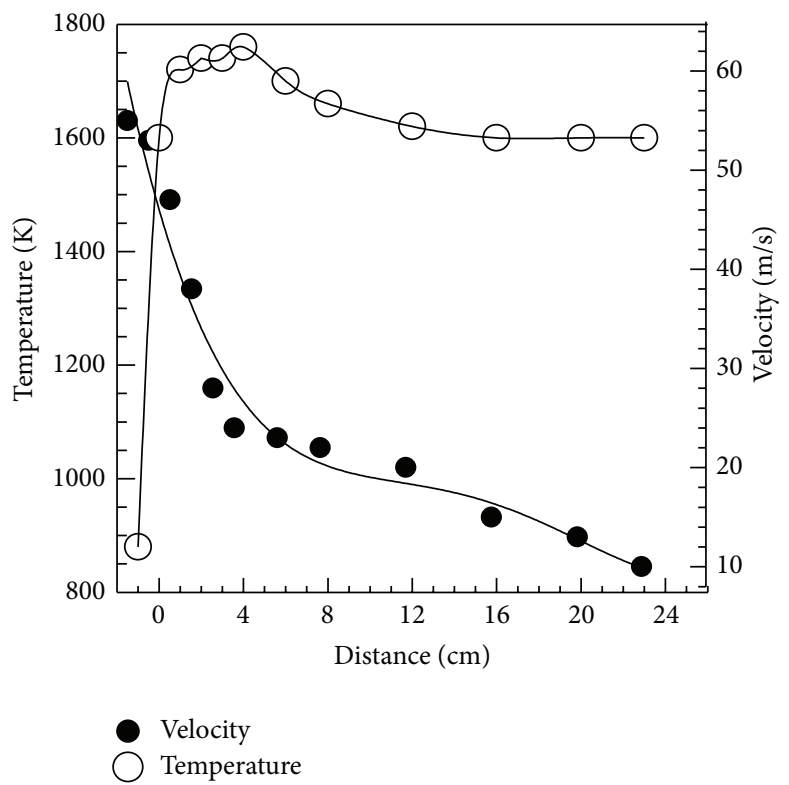

(b)

FIGURE 2: Concentrations, gas flow velocity, and flame temperature for turbulent premixed light diesel-air flame at Reynolds number $12.139 \times$ $10^{3}$, inlet temperature $673 \mathrm{~K}$, solidity ratio 0.68 , equivalence ratio 1.25 , and pressure 1 bar.

TABLE 1: Properties of diesel and kerosene fuels.

\begin{tabular}{|c|c|c|c|}
\hline Test properties & Test method & Diesel fuel & Kerosene \\
\hline Chemical formula & & $\mathrm{C}_{12} \mathrm{H}_{26}$ & $\mathrm{C}_{10} \mathrm{H}_{22}$ \\
\hline Cetane number & ASTM D613 & 44.5 & 45.4 \\
\hline Flash point $\left({ }^{\circ} \mathrm{C}\right)$ & ASTM D93 & 52 & $45.6-46.4$ \\
\hline Pour point $\left({ }^{\circ} \mathrm{C}\right)$ & ASTM D97 & -32 & -49 \\
\hline Boiling point $\left({ }^{\circ} \mathrm{C}\right)$ & Oil weathering system & 369 & $200-260$ \\
\hline Self-ignition temperature $\left({ }^{\circ} \mathrm{C}\right)$ & ASMT D97 & 725 & 640 \\
\hline Distillation temp. $\left({ }^{\circ} \mathrm{C}\right) 90 \%$ & STM D86 & $228-338$ & $153-245$ \\
\hline Lower heating value (MJ/kg) & STM D240 & 45.9 & 45.6 \\
\hline Density at $40^{\circ} \mathrm{C},\left(\mathrm{kg} / \mathrm{m}^{3}\right)$ & 1298 TMDA & 830 & $760-810$ \\
\hline viscosity at $40^{\circ} \mathrm{C},\left(\mathrm{mm}^{2} / \mathrm{S}\right)$ & ASTMD445 & 3.1 & $1-1.9$ \\
\hline Sulfur content, wt $\%$ & ASTMD545 & 0.22 & 0.04 \\
\hline Carbon content, wt $\%$ & ASTM D5291 & 84.7 & 84.5 \\
\hline Hydrogen content, (wt\%) & ASTM D5291 & 15.3 & 15.5 \\
\hline Carbon/hydrogen ratio & & 5.53 & 5.45 \\
\hline Sulfur content, \% & ASTM D5453-39 & 0.16 & 0.04 \\
\hline Paraffin content, Vol.\% & ASTM D 2007 & $41.3-52.4$ & $47-55$ \\
\hline Aromatic content, Vol.\% & ASTM method D 2007 & $23.6-24.7$ & $15.5-19.6$ \\
\hline Olefin content, Vol.\% & ASTM method D 2007 & $18-30$ & $1.3-2.5$ \\
\hline Naphthalene, content Vol.\% & ASTM method D 2007 & $2.8-8.2$ & 2.8 \\
\hline Saturates content, Vol.\% & ASTM method D 2007 & $79.3-75.3$ & $79-82$ \\
\hline
\end{tabular}


condition for all stable species, and (3) quenching effect due to heat loss to the surrounding. Many elementary reactions explain the conversion of $\mathrm{CO}$ to $\mathrm{CO}_{2}$ as follows:

$$
\begin{gathered}
\mathrm{CO}+\mathrm{HO} \longleftrightarrow \mathrm{CO}_{2}+\mathrm{H} \\
\mathrm{CO}+\mathrm{O} \longleftrightarrow \mathrm{CO}_{2}+h_{v} \\
\mathrm{CO}+\mathrm{O}+\mathrm{M} \longleftrightarrow \mathrm{CO}_{2}+\mathrm{M} \\
\mathrm{CO}+\mathrm{H}_{2} \mathrm{O} \longleftrightarrow \mathrm{CO}_{2}+\mathrm{H}_{2}
\end{gathered}
$$

Reaction (R2) contributes by $3-5 \%$ to $\mathrm{CO}$ conversion, El Kotb et al. [13]. The contribution of reactions (R1)-(R4) to the conversion rate is in order of $1 \times 10^{-5}$ mole $\mathrm{cm}^{-3} \mathrm{~s}^{-1}$. CO conversion is ascribed to reactions (R1)-(R4) even in the early stage of flame. In the main reaction zone, $\mathrm{H}_{2}$ formation rate is significantly higher due to heavy fuel which decomposes into light hydrocarbons and $\mathrm{H}_{2}$. This is true where the peak value of $\mathrm{H}_{2}$ attained after disappeared or decreased light hydrocarbons.

The principal peak of $\mathrm{H}_{2}$ formation rate which locates close to the burner tip is due to high rate of primary reaction as follows:

$$
\mathrm{C}_{\alpha} \mathrm{H}_{\beta}+\mathrm{H} \longleftrightarrow \mathrm{C}_{\alpha} \mathrm{H}_{\beta-1}+\mathrm{H}_{2}
$$

In the main reaction zone, the high rate of hydrogen formation is explained by molecular diffusion. $\mathrm{H}_{2}$ and $\mathrm{CO}$ formation rates increase while $\mathrm{H}_{2} \mathrm{O}$ formation rate decreases due to the occurrence of the following reaction:

$$
\mathrm{C}+\mathrm{H}_{2} \mathrm{O} \longleftrightarrow \mathrm{H}_{2}+\mathrm{CO}
$$

Also, $\mathrm{H}_{2}$ formation rate increases with increased $\mathrm{CO}$ formation rate and vice versa. $\mathrm{H}_{2}$ formation starts nearly after one $\mathrm{cm}(0.5 \mathrm{~ms})$ from burner tip due to low flame temperature and is explained by probe quenching effect. Formation rate of unburned hydrocarbons (UHC) decreases rapidly after $5 \mathrm{~cm}(6 \mathrm{~ms})$ from burner tip. The reaction rates of (R1)-(R6) decrease rapidly due to decreasing flame temperature. In the postflame zone, the primary reaction is as follows:

$$
\mathrm{H}_{2} \mathrm{O}+\mathrm{H} \longleftrightarrow \mathrm{H}_{2}+\mathrm{OH}
$$

This reaction has relatively high activation energy of $8484 \mathrm{~kJ} / \mathrm{mole}$. In the postflame zone the rate of reaction decreases rapidly due to decreasing flame temperature. The relative decrease in $\mathrm{H}_{2}$ formation rate is a result of combined effect of reactions (R5) and (R7). Near the flame end (after long residence time), all heavy fuel, light hydrocarbons, and intermediate species are nearly consumed. Consequently, all $\mathrm{H}_{2}$ molecules approximately burned and disappeared. Near burner tip, unburned hydrocarbon (ethane, ethylene, and propane) formation rates are high due to decomposition of the existing heavy fuel, maximum $\mathrm{O}_{2}$ concentration, and high gradient of flame temperature. Once the unburned mixture issues from the burner tip and ignition starts, many reactions in the pyrolysis zone produce unstable intermediate species which disintegrates to produce products. The chemical structure of these species depends upon the rate of reaction of each species which mainly depends on the flame temperature, pressure, fuel structure, and time lag after start of the reaction. In rich flame, the concentrations of unstable hydrocarbon components are higher than in lean flame. The amount of unstable intermediate hydrocarbons having an even number of carbon atoms has more frequency to react than those with an odd number regardless of the fuel used, Akrich et al. [15]. The hydrocarbon profiles are steeper in formation and dissipation due to high gradient of flame temperate which increases the activity and tendency of hydrocarbons to react with the oxidizer. Propane attains its maximum value before ethane because propane is heavy than ethane and is considered as a source for ethane formation. Because propane has carbon/hydrogen ratio higher than ethane, so propane decomposes to ethane component and other intermediate components according to the following reaction:

$$
\mathrm{C}_{3} \mathrm{H}_{8} \longleftrightarrow \mathrm{C}_{2} \mathrm{H}_{6}+\mathrm{CH}_{2}
$$

Also, ethylene attains its maximum value before propane because ethylene has high carbon/hydrogen ratio and also double bond between carbon atoms. Consequently, propane decomposes into ethylene and other intermediate components according to the following reaction:

$$
\mathrm{C}_{3} \mathrm{H}_{8} \longleftrightarrow \mathrm{C}_{2} \mathrm{H}_{4}+\mathrm{CH}_{4}
$$

Primarily, ethane forms in the flame by reaction involving methyl radicals. The concentrations of these species and their primary intermediate products $\mathrm{C}_{2} \mathrm{H}_{5}, \mathrm{C}_{2} \mathrm{H}_{4}, \mathrm{C}_{2} \mathrm{H}_{3}, \mathrm{C}_{2} \mathrm{H}_{2}$, $\mathrm{CH}_{2}$, and $\mathrm{CH}$ are small. These low levels underscore the dominance of the mechanistic paths which proceed by way of $\mathrm{CH}_{2} \mathrm{OH}$ and $\mathrm{CH}_{2} \mathrm{O}$, rather than through $\mathrm{CH}_{3}$, Westbrook and Dryer [16]. The relative rates of individual elementary reactions vary across the flame and induction zones.

The flame temperature at exit of the burner is higher than temperature of the exit mixture from the perforated plate. The increase in temperature attributes to preheating of unburned mixture within holes of the perforated plate and radiative heat to thermocouple by the plate of the flame holder. In the main reaction zone, the burning rate is high due to high gradient of flame temperature. But in the postflame zone, gradient of flame temperature is low due to complete combustion and equilibrium condition. In the main reaction zone, based on heat and mass transfer from the recirculation zone, gradient of flame temperature is high. In the recirculation zone (regions between each two adjacent potential cores), the hot gases mix with cool gases at a point of high $\mathrm{O}$ atoms concentrations, and, consequently, high gradient of the flame temperature. Radhakrishnan et al. [17] observed that flame temperature increased by $200 \mathrm{~K}$ corresponding to less than $25 \%$ of recirculation gases; consequently radical species are consumed early. In the main reaction zone, the over temperature attributes to the actual finite rates of reactions and the diffusion of the heat release due to chemical reactions. In the neighborhood of the main reaction zone, where most of the unburned gases react rapidly and not appear as cold eddies, the flame temperature remains high. Furthermore, in the main reaction zone, the over temperature attributes to high temperature fluctuation resulting from (1) 


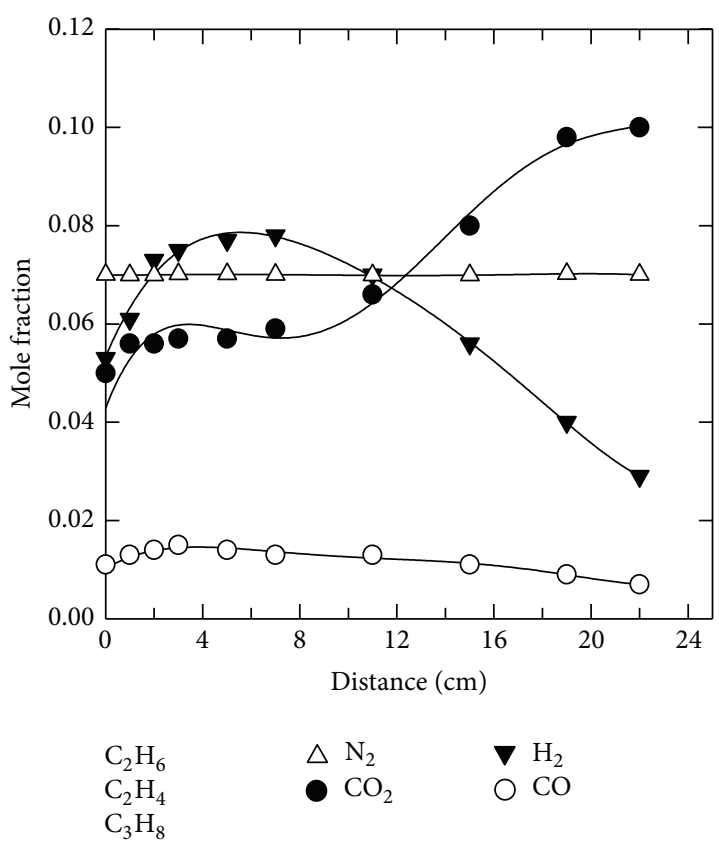

(a)

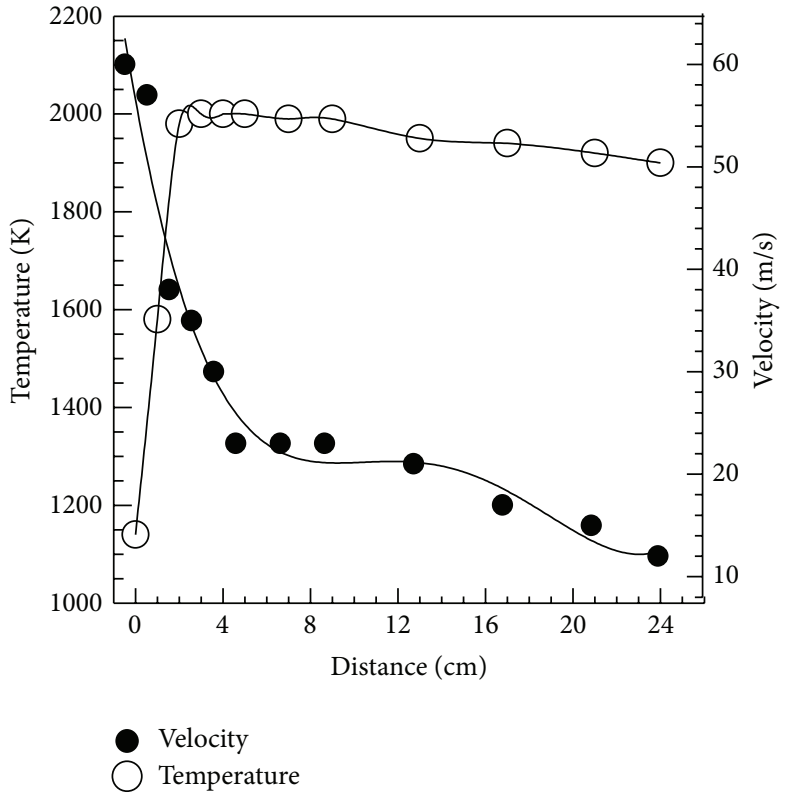

(b)

FIGURE 3: Concentrations, gas flow velocity, and flame temperature for turbulent premixed kerosene-air flame at Reynolds number $12.139 \times$ $10^{3}$, inlet temperature $573 \mathrm{~K}$, solidity ratio 0.68 , equivalence ratio 1.25 , and pressure 1 bar.

the variations of the local gases concentrations, (2) increasing rate of reaction due to presence of cold and hot eddies in turbulent flame, and (3) high temperature gradient with a high degree of turbulence. Outside the main reaction zone, a rapid decrease in temperature is observed as the energy convection and conduction away from the hot flame region. Also, near end of flame, flame temperature decreases due to heat transfer and cooling effect of the surrounding.

The axial velocity remains nearly constant for $2 \mathrm{~cm}$ $(0.5 \mathrm{~ms})$ from burner tip due to potential core effect. Actually, mixture passing through the perforated plate with hole diameter $2.9 \mathrm{~mm}$ gives a potential core length equals 20 times the hole diameter extending downstream the hot air flow. Furthermore, as unburned mixture exits from burner tip, flow velocity increases to high value due to increase flame temperature and decrease gas density. Thereafter, flame cross section area increases due to expand and spread of the flow and, consequently, flow velocity decreases steeply. The drop in flow velocity occurs early and rate of decreasing length of the potential core for flame is higher than that for cold flow. Moreover, at the end of the potential core and the beginning of the main reaction zone, flow velocity decreases due to effect of turbulence, where small change in axial and radial flow velocities and existing of recirculating gases. Beyond the main reaction zone, gas flow velocity profile decreases continuously until (at distance from burner tip that is nearly 31 times hole diameter) its shape becomes uniform and nearly no change occurs any longer with increased distance from burner tip.

3.2. Effect of Fuel Type on Combustion Process. The effect of fuel type on combustion process for turbulent prevaporized premixed light diesel-air flame is shown in Figure 2 and for kerosene-air flame is shown in Figure 3. Light dieselair flame has reaction zone length longer than keroseneair flame due to high $\mathrm{C} / \mathrm{H}$ ratio and double bonds between carbon atoms which need longer residence time and high flame temperature for complete combustion. Also, maximum burning velocity decreases with increased carbon atoms in the fuels. For lean flame, kerosene-air flame has reaction zone length longer than light diesel-air flame due to cooling effect of excess air which decreases rate of reaction and burning velocity. In the main reaction zone, light diesel-air flame emits $\mathrm{UHC}$ and $\mathrm{H}_{2}$ higher than kerosene-air flame due to high percentage of olefins and aromatics. The rate of reaction decreases with increased carbon bonds, so UHC profiles extend to long distance along the flame. Also, for light dieselair flame, rate of decreasing $\mathrm{CO}$ is lesser than for keroseneair flame. This is due to existence of UHC in flame which is considered as a source for CO formation. For keroseneair flame after $3 \mathrm{~cm}$ (one millisecond) all hydrocarbons are nearly burned and $\mathrm{CO}$ decreases due to absence sources of CO formation. Regarding light diesel-air flame, rate of formation of $\mathrm{CO}_{2}$ increases continuously in the postflame zone, but for kerosene-air flame rate of formation of $\mathrm{CO}_{2}$ decreases to low value where all fuel is consumed in the main reaction zone and equilibrium occurred early. Furthermore, since kerosene fuel contains paraffin higher than light diesel fuel, it is easy to crack atomic bonds and need less residence time for complete combustion. In contrast, kerosene-air flame emits high $\mathrm{H}_{2}$ concentration especially in the main reaction zone where kerosene fuel has $(\mathrm{H} / \mathrm{C})$ ratio higher than light diesel fuel. For kerosene-air flame, the decreasing rate of $\mathrm{H}_{2}$ is lower than light diesel-air flame where it attains equilibrium condition (complete combustion) early. Also, 
near end of flame, kerosene-air flame has flame temperature higher than light diesel-air flame. Also, in the main reaction zone, light diesel-air flame has flame temperature lower than kerosene-air flame due to pyrolysis of fuel to free radicals and intermediate species is lesser and the reaction zone length is longer. For light diesel-air flame, flame temperature reaches its maximum value after that its decreases with higher rate than kerosene-air flame. This is due to early burning of paraffin content near burner tip with the same burning rate as for kerosene fuel. Thereafter, olefins and aromatics begin to burn but with lower rates than paraffin. So, for light diesel-air flame, rate of heat release and rate of increasing flame temperature are lesser than keroseneair flame. High efforts are done to correlate adiabatic flame temperature for light diesel and kerosene-air flames. From plotting experimental data of flame temperature along flame axis for different operating conditions (different equivalence ratio, different Reynolds number, different inlet temperatures, and different holes diameter of perforated plate) the adiabatic flame temperatures are correlated as follows.

For light diesel fuel: consider the following.

(1) $\operatorname{For} \phi>1$

$$
T_{\text {adiabatic }}=2100 \phi^{-0.219} \zeta \theta^{Z} \Psi^{Y},
$$

where $\zeta=\operatorname{Exp}(0.4038 \phi-1.502)^{2} ; Y=0.01-0.13 \phi+$ $0.08 \phi ; Z=0.571-0.552 \phi+0.131 \phi^{2}$ and

(2) for $\phi<1$

$$
T_{\text {adiabatic }}=2310 \phi^{-0.052} \zeta \theta^{Z} \Psi^{Y},
$$

where $\Psi=\mathrm{H} / \mathrm{C}$, and $\theta=\left(T_{i} / T_{0}\right) ; \quad \zeta=$ $\operatorname{Exp}\left(-(1.05 \phi-1.253)^{2}\right) ; Y=0.573-0.552 \phi+0.132 \phi^{2}$; $Z=0.011-0.133 \phi+0.081 \phi^{2}$.

For kerosene fuel: consider the following.

(1) For $\phi>1$

$$
T_{\text {adiabatic }}=2310 \phi^{0.3029} \zeta \theta^{Z} \Psi^{Y},
$$

where $\zeta=\operatorname{Exp}(0.40038 \phi-1.422)^{2} ; Y=0.22-0.442 \phi+$ $0.132 \phi^{2} ; Z=0.181-0.312 \phi+0.0918 \phi^{2}$ and

(2) for $\phi<1$

$$
T_{\text {adiabatic }}=2310 \phi^{0.12} \zeta \theta^{Z} \Psi^{Y},
$$

where $\zeta=\operatorname{Exp}\left(-(0.9097 \phi-1.07)^{2}\right) ; Y=0.011-$ $0.131 \phi+0.0832 \phi^{2} ; Z=0.3961-0.441 \phi+0.141 \phi^{2}$,

where $T_{i}$ and $T_{o}$ are inlet and atmospheric temperatures, respectively, $\mathrm{K}$.

3.3. Effect of Fuels Blends on Combustion Process. The purpose of fuel blending is to improve quality of combustion process to increase flame temperature. Diesel and kerosene fuels have different physical and chemical properties such as chemical structures, viscosity, heating value, self-ignition temperature, boiling temperature, adiabatic flame temperature, difference contents of paraffin, aromatic, olefin, naphthalene, and saturates hydrocarbon as listed in Table 1 . There are many engineering applications for blending diesel/kerosene/gasoline fuels for internal combustion engines, Obodeh and Isaac [7], Ghormade and Deshpande [8], and Kumar Reddy [9]. So, blending kerosene with light diesel fuel is one of the major parameters for the present work. Effects of fuels blends on combustion process for rich and lean turbulent prevaporized premixed hydrocarbon-air flames at different residence time are shown in Figures 4, 5, and 6. Actually concentrations, flow velocity, and flame temperature are measured for different operating conditions along flame axis. After that from flow velocity and distance above burner tip for different operating conditions, the residence time at each location is calculated to obtain Figure 4 to Figure 10 for different residence time with different operating conditions.

For rich mixture, reaction zone length increases with increased light diesel percentage in the blend. So, residence time for complete combustion increases with increased light diesel percentage. Consequently, CO and UHC concentrations increase with increased light diesel percentage. Also, $\mathrm{CO}_{2}$ profiles for different blends are nonsmooth due to different percentages of paraffin, olefin, and aromatic in blends where all these components have different rates of reaction and burned at different stages in flame (paraffin, olefin, and aromatic, resp.). So, paraffin burns near burner tip while olefin begins to burn after $4 \mathrm{~ms}$ from burner tip. Furthermore, flame temperature and flow velocity profiles increase with increased kerosene percentage. In the postflame zone $(16 \mathrm{~ms})$, rate of decreasing flame temperature increases with decreased light diesel percentage. For rich mixture, length of reaction zone increases with increased light diesel percentage. So, residence time for complete combustion increases with increased light diesel percentage. So, percentage of $\mathrm{CO}$ and UHC increases with increased light diesel percentage. At residence time of $3 \mathrm{~ms}, \mathrm{CO}_{2}$ profile is steeper with increased kerosene percentage due to increase flame temperature.

Also, $\mathrm{H}_{2}$ concentration increases with increased kerosene percentage due to increasing $(\mathrm{H} / \mathrm{C})$ ratio. Maximum flame temperature increases with increased kerosene percentage in the blend. In the main reaction zone $(3 \mathrm{~ms})$, effect of fuel blending on flow velocity is less than in the postflame zone $(16 \mathrm{~ms})$ and for lean flame is higher than for rich flame. Effect of blending on flame temperature and flow velocity is higher than effect of blending on concentrations except for $\mathrm{H}_{2}$. Effect of blending on combustion process in main reaction zone $(3 \mathrm{~ms})$ is smaller than in the postflame zone. The effects of kerosene percentage for lean and rich flames are not linear dependent. As light diesel percentage increases, $\mathrm{CO}$ and $\mathrm{CO}_{2}$ concentrations increase. As light diesel percentage in the flame increases, rate of increasing $\mathrm{CO}_{2}$ for rich flame is lesser than for lean flame due to insufficient oxygen, which decreases radical concentrations and flame temperature. In the main reaction zone, rate of increasing $\mathrm{CO}$ for lean and rich flames is steeper with light diesel percentage greater than $50 \%$. As light diesel percentage increases, rate of decreasing $\mathrm{H}_{2}$ for rich flame is higher than for lean flame especially in the 

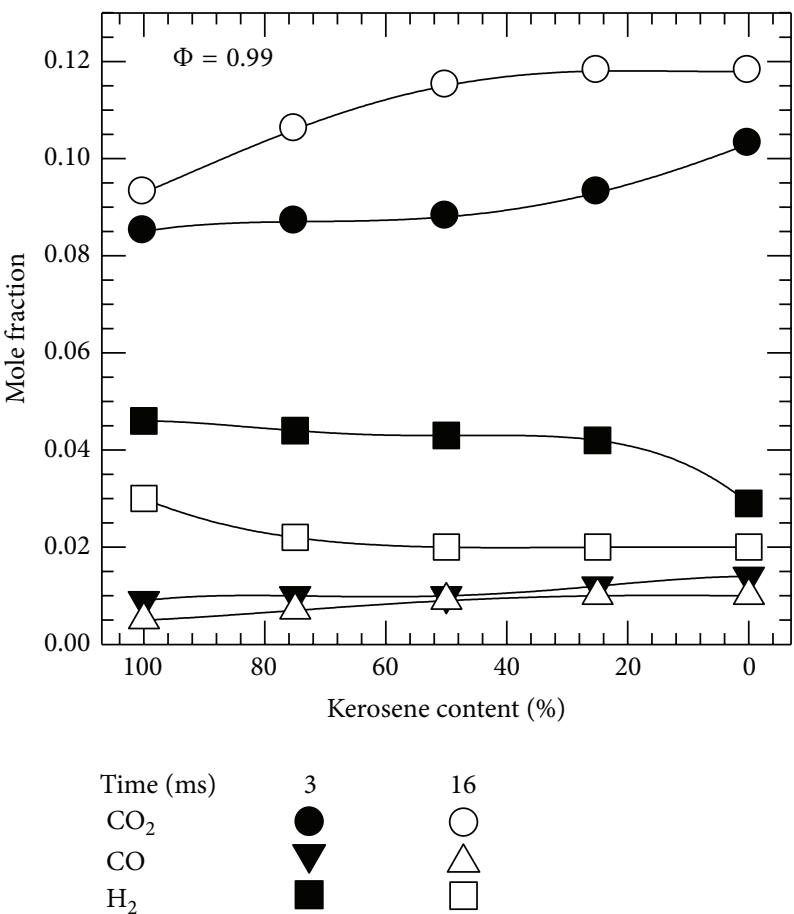

(a)
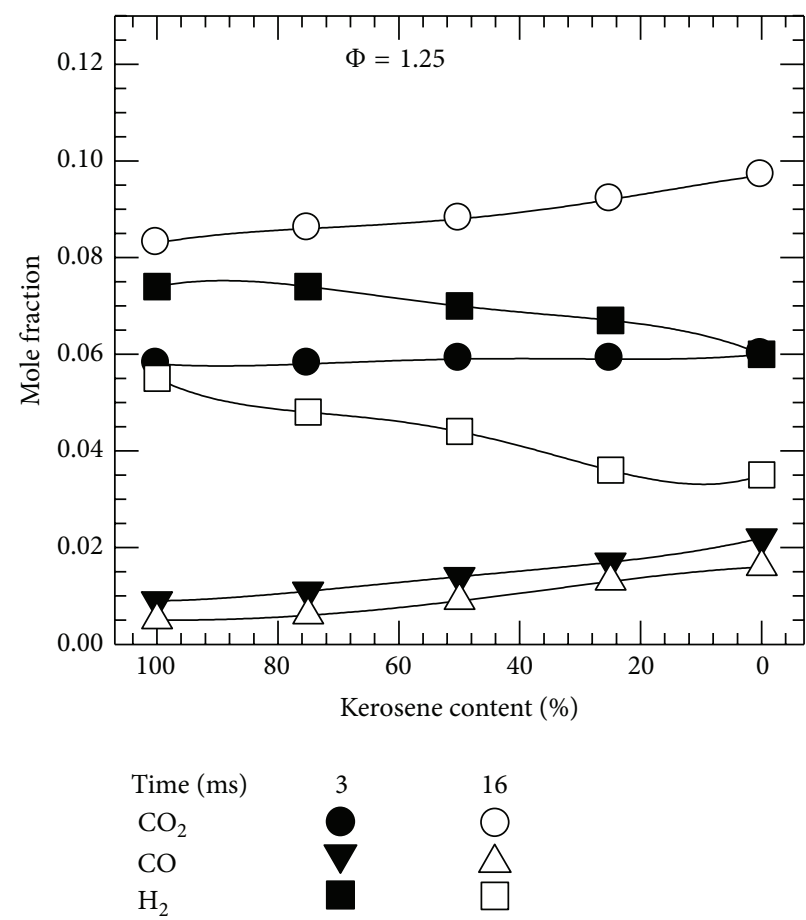

(b)

FIGURE 4: Effect of kerosene content on concentrations for turbulent premixed kerosene light diesel blends-air flame for different equivalence ratios and residence time with $\mathrm{Re}=11.08 \times 10^{3} 00$ and solidity ratio $=0.68$.

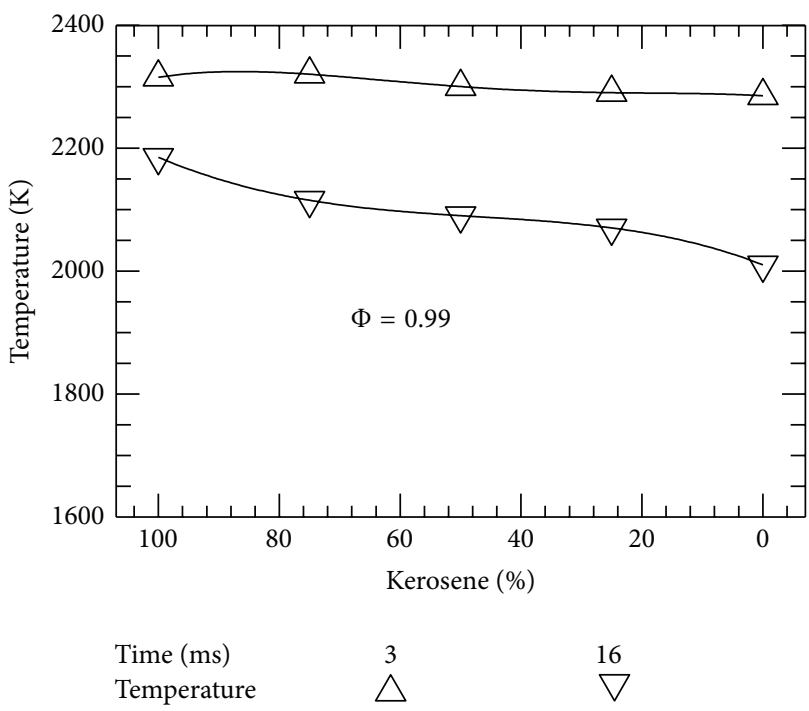

(a)

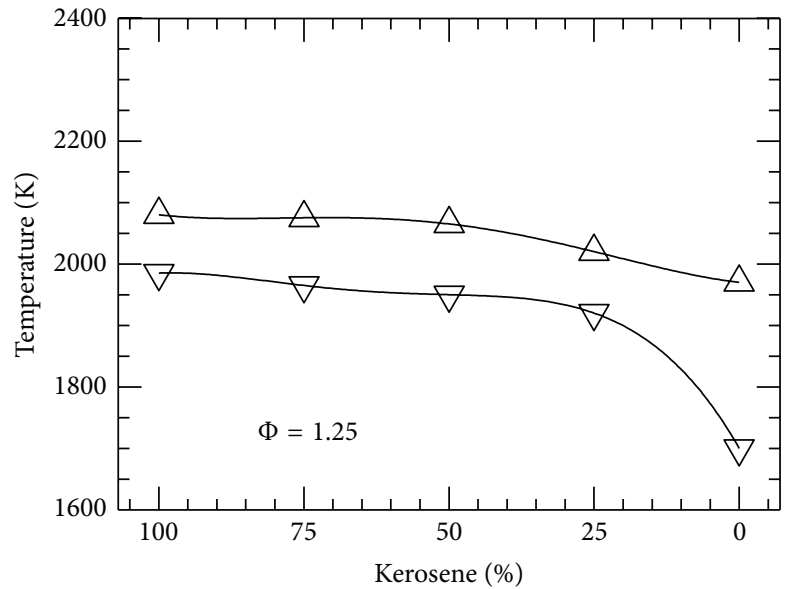

Time (ms)
Temperature

(b)

FiguRE 5: Effect of kerosene content on flame temperature for turbulent premixed kerosene light diesel blends-air flame for different equivalence ratios and residence time with $\mathrm{Re}=11.08 \times 10^{3}$ and solidity ratio $=0.68$.

postflame zone. As light diesel percentage increases, rate of decreasing flame temperature and flow velocity for lean flame are higher than for rich flame especially in the postflame zone.

3.4. Effect of Equivalence Ratio on Combustion Process. Effects of equivalence ratio on combustion process for light diesel and kerosene-air flames at different residence times are shown in Figure 7. For kerosene-air flame rate of increasing $\mathrm{H}_{2}$ is higher than for light diesel-air flame due to high $(\mathrm{H} / \mathrm{C})$ ratio. The maximum $\mathrm{CO}_{2}$ concentration and flame temperature for light diesel-air flame are more compatible than for kerosene-air flame. For rich flame, rate of decreasing $\mathrm{CO}_{2}$ for 


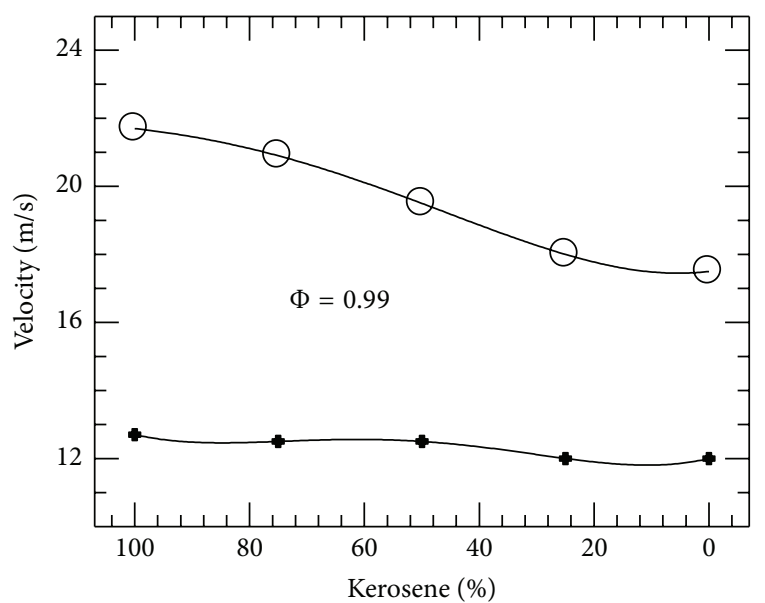

Time (ms) Velocity
16

○

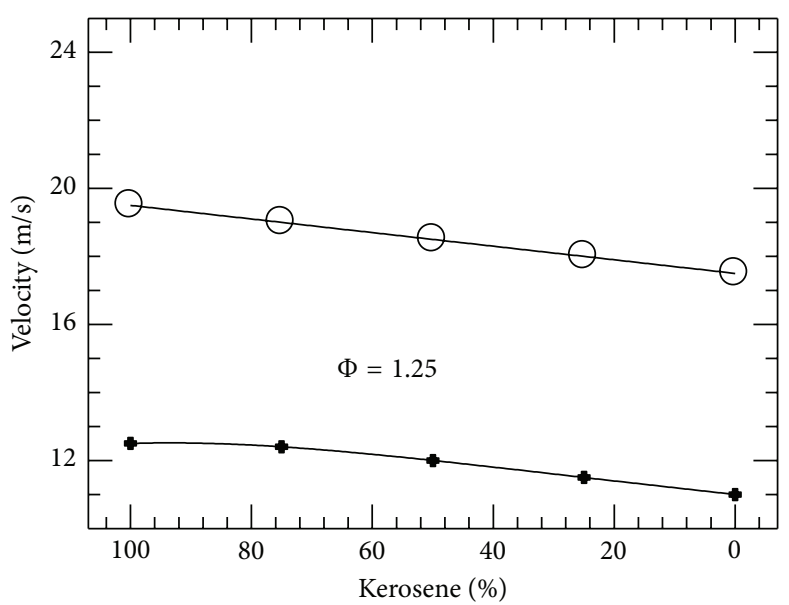

Time (ms) Velocity

(a)

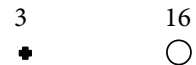

(b)

FIGURE 6: Effect of kerosene content on flow velocity for turbulent premixed kerosene light diesel blends-air flame for different equivalence ratios and residence time with $\mathrm{Re}=11.08 \times 10^{3}$ and solidity ratio $=0.68$.

kerosene-air flame is steeper than light diesel-air flame due to low $(\mathrm{C} / \mathrm{H})$ ratio. In contrast, for rich flame, in the postflame zone (at $20 \mathrm{~ms}$ ) (not present here), rate of decreasing $\mathrm{CO}_{2}$ for light diesel-air flame is steeper than for kerosene-air flame due to equilibrium which occurs earlier than light diesel-air flame. So, flame temperature profile for keroseneair flame is flatter than light diesel-air flame. Concentration profiles for lean flame are steeper than for rich flame due to excess $\mathrm{O}_{2}$ and $\mathrm{O}$ concentrations. For rich flame, the high organic radicals' concentrations lead to high formation rate of $\mathrm{CO}$. On the other hand, the low $\mathrm{O}$-atoms concentrations explain the low formation rate of $\mathrm{CO}_{2}$. For lean flame, as equivalence ratio decreases, length of reaction zone increases while residence time for the postflame zone decreases. For slightly rich mixture (adjacent to stoichiometric) $\mathrm{CO}_{2}$ has maximum value. For lean flame (at equivalence ratio less than $0.9)$ the drop in flame temperature is high due to cooling effect of excess air which increases length of reaction zone and decreases $\mathrm{CO}_{2}$ concentration. Also, for rich flame, $\mathrm{CO}_{2}$ gradually decreases due to decreasing radicals concentrations and flame temperature. The rate of conversion of $\mathrm{CO}$ to $\mathrm{CO}_{2}$ decreases due to poor oxygen and low flame temperature. Also, rate of formation of $\mathrm{CO}_{2}$ is low and its influences by the drop in flame temperature. In the main reaction zone, rate of formation of $\mathrm{CO}$ is fast due to fuel dissociation and excess $\mathrm{O}_{2}$ concentration. For rich flame, unsaturated hydrocarbons contain more carbon atoms as a source for CO formation. The maximum concentration of $\mathrm{CO}$ increases with increased equivalence ratio. In the main reaction zone, rate of formation of $\mathrm{CO}$ decreases due to oxidization of $\mathrm{CO}$ to $\mathrm{CO}_{2}$ according to (R1). In the postflame zone, $\mathrm{CO}$ concentration is minimum (equilibrium condition) due to complete combustion. At stoichiometric condition, $\mathrm{CO}$ concentration is high due to dissociation of $\mathrm{CO}_{2}$ at high temperature. For rich flame, rate of formation $\mathrm{CO}$ increases due to lack of oxygen concentration. For lean flame, $\mathrm{CO}$ concentration is high due to decrease rate of reaction of (R1) (thermal quenching). For lean flame, $\mathrm{CO}$ concentration is considered as an indication of thermal quenching in postflame zone. According to reaction (R1) rate of oxidation $\mathrm{CO}$ decreases due to decreasing flame temperature leading to high $\mathrm{CO}$ concentration. For rich flame, rate of formation of $\mathrm{CO}$ increases due to decreasing flame temperature and insufficient $\mathrm{O}_{2}$ concentration for complete combustion leading to decreased rate of reaction. As equivalence ratio decreases, rate of decreasing $\mathrm{H}_{2}$ is steeper due to increasing flame temperature and rate of reaction. But, for rich flame as equivalence ratio increases, flame length increases while flame temperature decreases. Consequently, high UHC concentration exists as a source for $\mathrm{H}_{2}$ formation. In the main reaction zone (at $4.5 \mathrm{~ms}$ ), $\mathrm{H}_{2}$ profile is steeper than in the postflame zone $(20 \mathrm{~ms})$ due to decreasing rate of reaction of different species and equilibrium condition. For rich flame, there is low tendency to form free radical species $\mathrm{HCO}, \mathrm{O}, \mathrm{OH}, \mathrm{CH}, \mathrm{H}, \mathrm{HO}$, and $\mathrm{HCN}$ which forms many intermediate reactions for oxidation $\mathrm{UHC}$ and $\mathrm{H}_{2}$. The rapid decays of $\mathrm{HCN}$ do not take place until UHC is almost disappeared. So, stable intermediate species $\mathrm{CO}, \mathrm{H}_{2}, \mathrm{C}_{2} \mathrm{H}_{4}, \mathrm{C}_{2} \mathrm{H}_{6}$, and $\mathrm{C}_{3} \mathrm{H}_{8}$ increase monotonically with increased equivalence ratio. For rich flame, as equivalence ratio increases, $\mathrm{H}_{2} \mathrm{O}$ decreases while $\mathrm{CO}$ and $\mathrm{H}_{2}$ concentrations increase according to (R6). For lean flame, flame temperature decreases with decreased equivalence ratio due to cooling effect of excess air. As equivalence ratio increases by $12 \%$, maximum flame temperature increases by $16 \%$. For rich flame, as equivalence ratio increases by $16 \%$, maximum flame temperature decreases by $35 \%$.

Therefore, for rich flame, effect of equivalence ratio on the maximum flame temperature is greater than for lean flame. In the main reaction zone (at $5.4 \mathrm{~ms}$ ), flame temperature is steeper than in the postflame zone (at $20 \mathrm{~ms}$ ) due to 


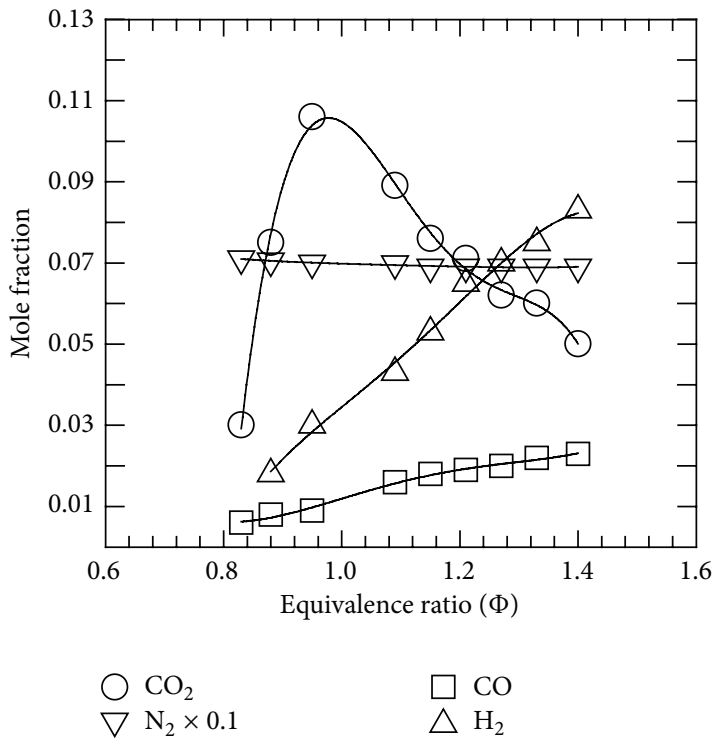

(a)

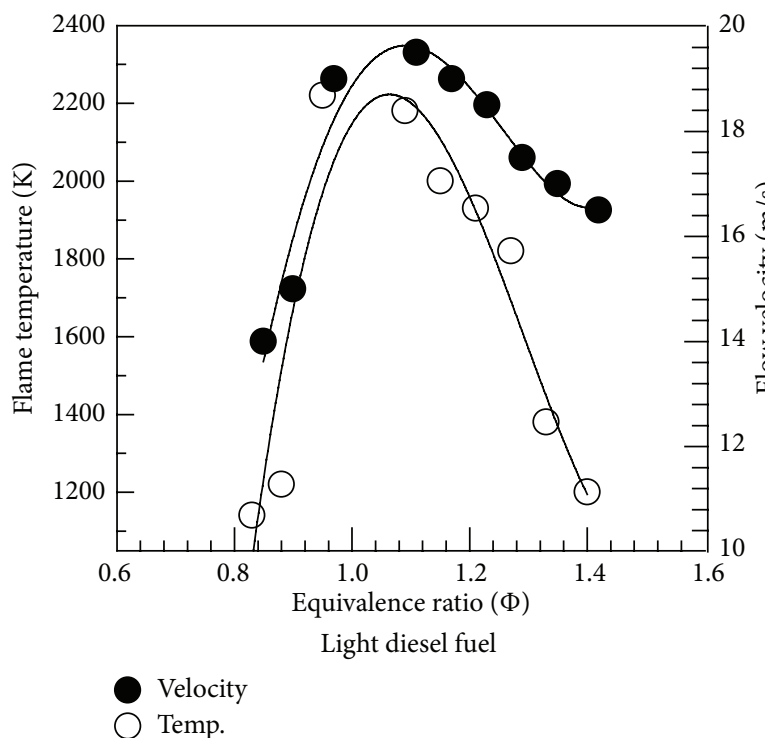

(c)

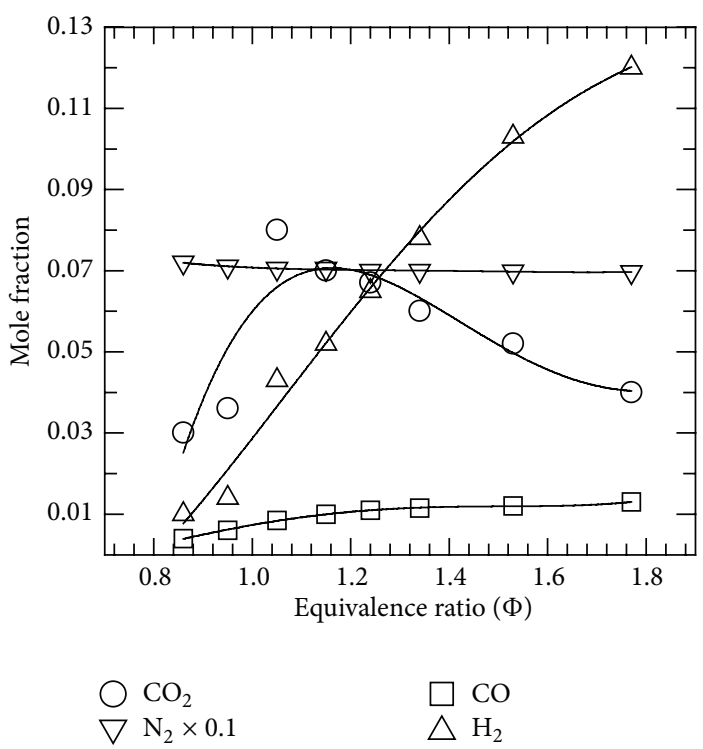

(b)

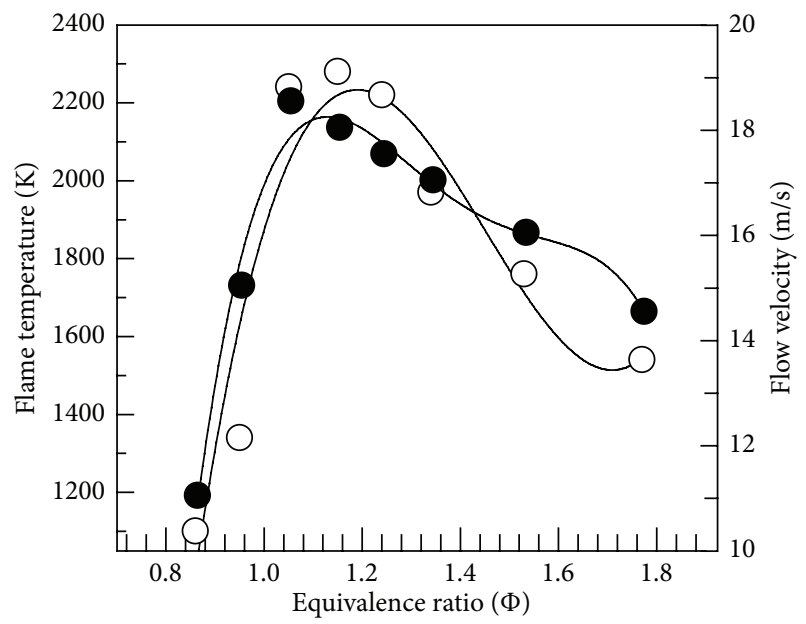

Kerosene fuel

Velocity

$\bigcirc$ Temp.

(d)

FIGURE 7: Effect of equivalence ratio on flame structure for turbulent premixed-air flame at residence time 5.4 ms, Reynolds number $11.08 \times$ $10^{3}$, solidity ratio 0.68 , and pressure 1 bar.

equilibrium condition. For lean flame at $5.4 \mathrm{~ms}$, flow velocity profile is steep and increases with increased equivalence ratio due to increasing flame temperature. For rich flames, as equivalence ratio increases flow velocity decreases by rate lower than for lean flame. In the postflame zone (at $20 \mathrm{~ms}$ ), flow velocity profile is nearly straight line and decreases with increased equivalence ratio due to decreasing flame temperature overcoming the increase in fuel mass flow rate. The main effect of equivalence ratio on flow velocity appears in the main reaction zone with maximum flame temperature. $\mathrm{CO}$ concentration is high at low equivalence ratio due to low oxidation rate which associates with decrease in flame temperature. As equivalence ratio increases, flame temperature increases which accelerates oxidation rate and $\mathrm{CO}$ declines. At temperature higher than $1800 \mathrm{~K}$, formation of $\mathrm{CO}$ due to dissociation of $\mathrm{CO}_{2}$ is significant. At high equivalence ratios $\mathrm{CO}$ concentration is high due to equilibrium condition. Only in the fairly narrow range of equivalence ratios of 0.7 to 0.9 $\mathrm{CO}$ concentration is low.

3.5. Effect of Inlet Reynolds Number on Combustion Process. In the present work Reynolds (Re) number is calculated as follows:

$$
\operatorname{Re}=\frac{4\left(\dot{m}_{\mathrm{air}}+\dot{m}_{\mathrm{fuel}}\right)}{\pi \mu n d},
$$




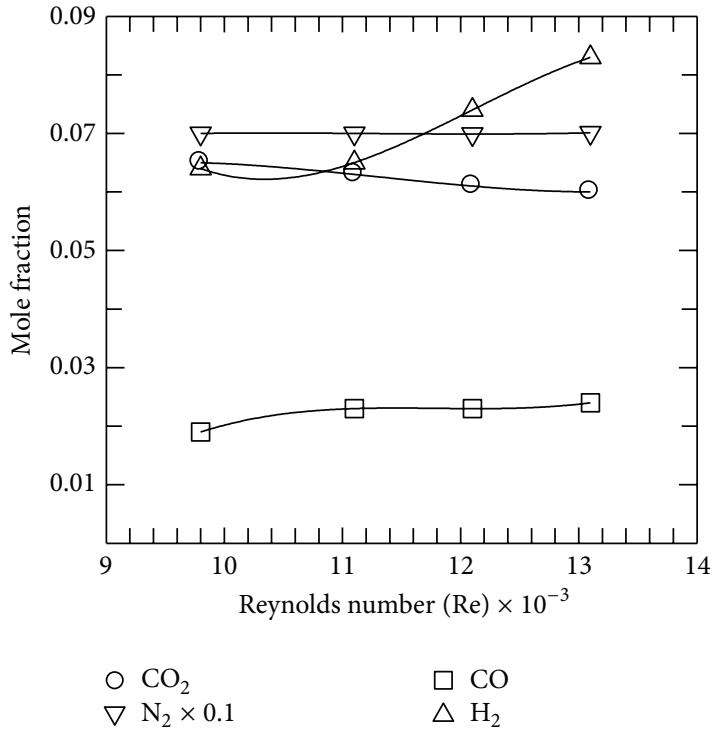

(a)

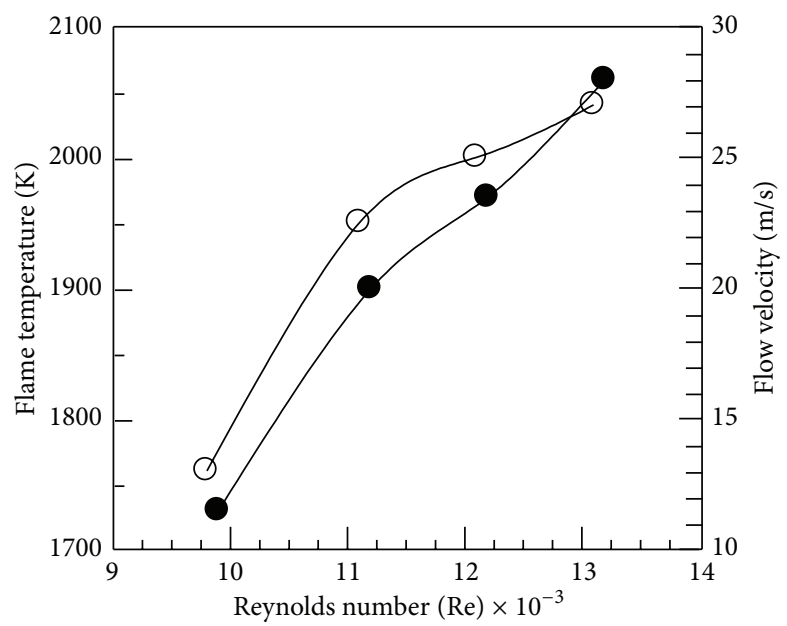

Light diesel fuel

Temp.

Velocity

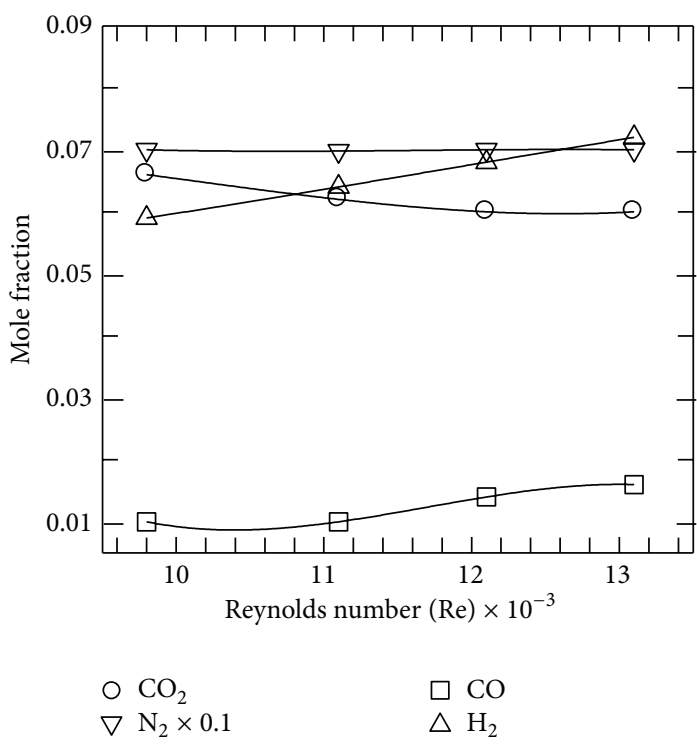

(b)

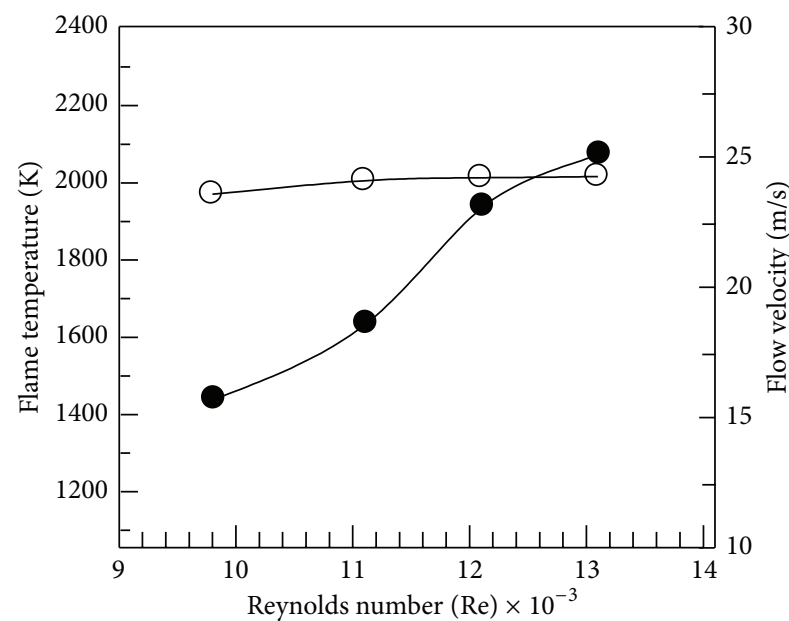

Kerosene fuel

Temp.

Velocity

(c)

(d)

FIGURE 8: Effect of Reynolds number on flame structure for turbulent premixed air flame at residence time 5.4 ms, solidity ratio 0.68 , and pressure 1 bar.

where

$\dot{m}_{\text {air }}$ is air mass flow rate, $\mathrm{kg} / \mathrm{s}$,

$\dot{m}_{\text {fuel }}$ is fuel mass flow rate, $\mathrm{kg} / \mathrm{s}$,

$d$ is hole diameter in flame holder perforated plate, $\mathrm{m}$, $n$ is number of holes in flame holder perforated plate, $\mu$ is kinematic viscosity of air at exit temperature from burner tip, $\mathrm{mm}^{2} / \mathrm{s}$.

Effect of inlet Reynolds number on combustion process for light diesel and kerosene-air flames is shown in Figure 8. As Reynolds number increases, the increasing rate of $\mathrm{CO}$ and $\mathrm{H}_{2}$ is higher than for $\mathrm{CO}_{2}$. As Reynolds number increases eddies inside the flame increase which increases flame temperature and rate of reaction of different species. As Reynolds number increases heat transfer between reacting and recirculating hot gases increases causing rate of flame propagation to increase. Consequently, flame temperature and rate of reaction of stable species increase. Also, high Reynolds number (high turbulence intensities) causes overshooting of $\mathrm{OH}, \mathrm{H}$, and $\mathrm{O}$ radicals concentrations leading to increasing rate of reaction and flame temperature. On the other hand, for high Reynolds number, $\mathrm{UHC}, \mathrm{H}_{2}$, and $\mathrm{CO}$ concentrations increase and they are not easily oxidized in the downstream due to decay flame temperature rapidly. This is due to high mixing of burned and unburned gases in recirculation zone and flame temperature is sufficiently high 
to oxidize $\mathrm{UHC}, \mathrm{CO}$, and $\mathrm{H}_{2}$. In contrast, in the postflame zone (20 ms not present here) $\mathrm{H}_{2}$ and $\mathrm{CO}$ concentrations decrease with increased Reynolds number due to increasing flame temperature which increases oxidization rate of $\mathrm{H}_{2}$ and CO. Effect of Reynolds number on concentration for light diesel-air flame is greater than for kerosene-air flames. Light diesel-air flame is more stable under high flame temperature than kerosene-air flames due to high $\mathrm{C} / \mathrm{H}$ ratio. As Reynolds number increases, the decreasing rate of $\mathrm{CO}_{2}$ for light dieselair flame is lesser than for kerosene-air flame and this is due to high $(\mathrm{C} / \mathrm{H})$ ratio in light diesel fuel. In contrast, as Reynolds number increases, increasing rate of $\mathrm{H}_{2}$ for kerosene-air flames is less than for light diesel-air flame.

Gas flow velocity increases with increased Reynolds number due to increasing air mass flow rate. Consequently, more expansion occurs inside the flame leading to early mixing of burned and unburned gases which improves combustion efficiency. Near burner tip, as inlet mixture velocity increases, recirculating gas increases which improves combustion efficiency due to increasing eddies and turbulence intensity. Indeed, the reaction rate is strongly dependent on relation between time $(t)$ of chemical conversion and frequency of velocity fluctuation. The rate of chemical reaction depends on the inhomogeneity of temperature and composition caused by turbulent fluctuation. The turbulent burning velocity increases linearly with increased inlet flow velocity and turbulence intensity. The gases along the flame axis accelerate by the prevailing buoyant which produces a large recirculation cell. The actual velocity measurements verify the existence of these cells. The presence of recirculating cells indicates the importance of buoyant effect on determining the overall flow pattern in the system. Due to these cells, the area of flow decreases and consequently flow velocity increases.

As Reynolds number increases, flame temperature increases gradually to $\mathrm{Re}=11 \times 10^{3}$. After that, rate of increasing flame temperature decreases due to dissociation effect. Furthermore, there are contradictions between $\mathrm{CO}_{2}$ profile on one hand and $\mathrm{CO}$ and $\mathrm{H}_{2}$ profiles on the other hand. In main reaction zone $(4 \mathrm{~ms})$, as Reynolds number increases, $\mathrm{CO}_{2}$ decreases but $\mathrm{CO}$ and $\mathrm{H}_{2}$ increase due to decrease residence time. In the postflame zone $(20 \mathrm{~ms})$, $\mathrm{CO}_{2}$ concentration increases but $\mathrm{CO}$ and $\mathrm{H}_{2}$ decrease due to complete combustion and equilibrium condition. In the main reaction and the postflame zones, Reynolds number effects on $\mathrm{H}_{2}$ are higher than other species. For light dieselair flame, Reynolds number effects on flame temperature are greater than for kerosene-air flame especially in the main reaction zone. So, effect of kerosene fuel on flow velocity is smaller than light diesel fuel. In the main reaction zone, as Reynolds number increases by $24 \%$ (from $9.912 \times 10^{3}$ to $13.1 \times 10^{3}$ ) flame temperatures of light diesel, kerosene-air flames increase by $200,50 \mathrm{~K}(18 \%, 10 \%)$, respectively. In the postflame zone, flames temperatures of light diesel and kerosene-air flames increase by $220,180 \mathrm{~K}$, respectively, for the same increase of Reynolds number.

3.6. Effect of Perforated Plate Holes Diameter on Combustion Process. Holes diameter is a main parameter for turbulence generation with premixed flame. For constant air and fuel mass flow rate, as holes diameter decreases inlet mixture velocity increases. The turbulent intensity varies according to plate geometry. At the burner exit, turbulence produces mainly by the perforated plate so the turbulent intensity is lager for a plate of small holes diameter. Turbulence decays in the core of the jet although its intensity increases in the core of the jet with increased distance from burner tip, because the turbulence is generated by shear mixing in the boundary of the jet. Many runs are carried out to determine the optimum holes diameter. If the flow velocity increases above a certain limit, the flames blow off from the burner rim like the conventional flame. On the other hand, if the flow velocity decreases to certain value, flame length decreases and finally flame becomes fuzzy at the burner tip. For small holes, diameter flow velocity is very high especially in main reaction zone, so there is an instantaneous boundary between burned and unburned gases, which is the flame front. The turbulent flame velocity increases with increased turbulence intensity due to the fact that turbulence intensity is proportional to the inlet flow velocity. Flow spreading angle determines the length of negative pressure zone (recirculation zone). Flow spreading angle decreases with decreased holes diameter so an increase in the spreading angle leads to decrease in recirculation zone length. High feed velocity gives small spreading angle and increases the negative pressure zone length, which increases recirculation of unburned gases at burner tip. Increasing recirculation zone length increases turbulence intensity, improves mixing of burned and unburned gases near burner tip, and also improves combustion efficiency. Moreover, as holes diameter decreases, flame length decreases causing an increase in the rate of heat release. On the other hand, for large holes diameter, reaction zone length is considerably longer than those observed for small holes diameter because of no rapidity of mixing burnt and unburnt gases as a result of absent recirculation effect. So, due to increasing reaction zone length, the residence time in the postflame zone reduces and finial $\mathrm{CO}_{2}$ level is found to be low. Studies of circulation zone sizes for grid plates are reasonable to assume as a function of holes diameter. The holes diameter is a more convenient parameter on base study of the recirculation zone size and the alternative is the web distance between holes which is a variable around the holes circumference. The central holes gave an annular recirculation zone rotating outwards and the web gives a central recirculation zone rotating inwards. Consequently mixing of burned and unburned gases improves. Effect of holes diameter on concentration, flame temperature, and gas flow velocity for turbulent premixed air flame of light diesel and kerosene-air flame are shown in Figure 9. From this figure, it can be noticed that the effect of holes diameter are mainly on gas flow velocity and flame temperature. Where gas flow velocity and flame temperature are compatible with each other and nearly decrease with the same rate. At the same time $\mathrm{H}_{2}$, $\mathrm{CO}$ increase as holes diameter increases but $\mathrm{CO}$ increases up to $3 \mathrm{~mm}$ as hole diameter, after that $\mathrm{CO}$ is kept constant. Furthermore, $\mathrm{CO}_{2}$ decreases with increased holes diameter up to $3 \mathrm{~mm}$ after that it is kept constant due to decreasing flame temperature, burning velocity, rate of 


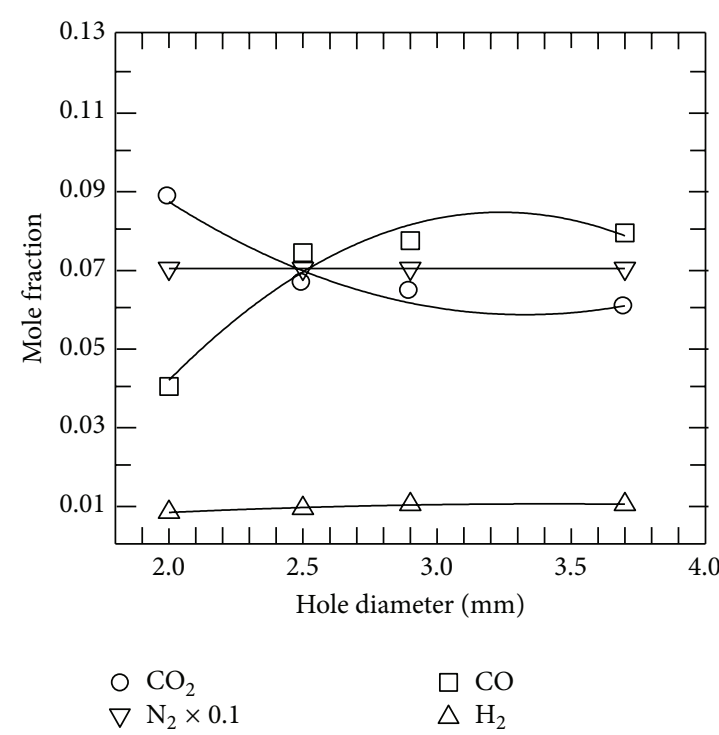

(a)

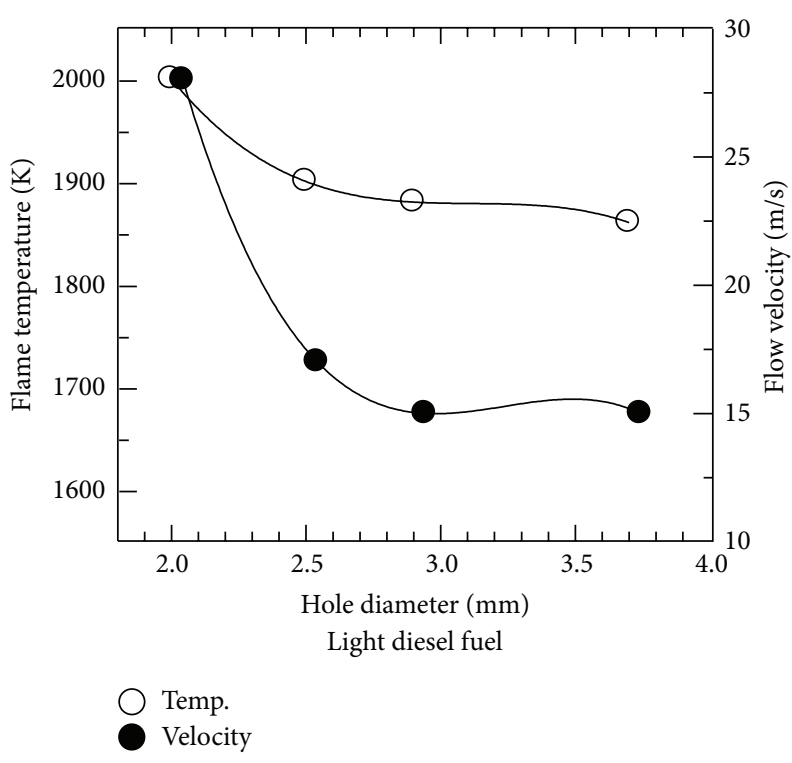

(c)

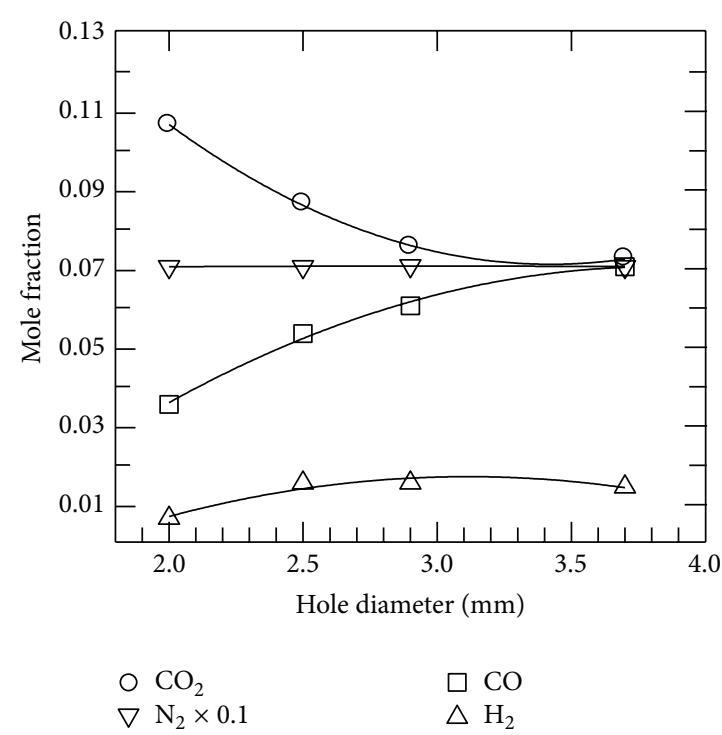

(b)

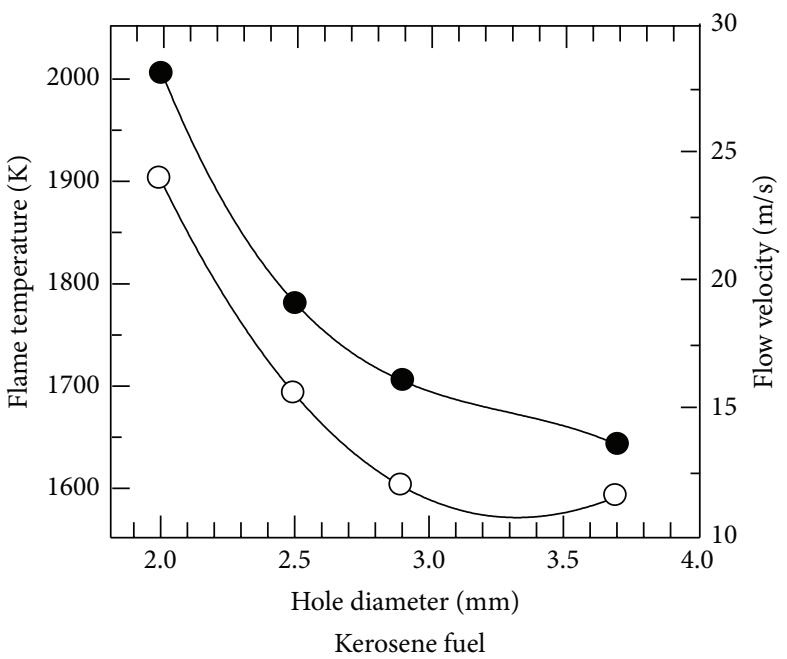

Temp.

Velocity

FIGURE 9: Effect of perforated plate holes diameter on flame structure for turbulent premixed air flame at residence time 5 ms, mean Reynolds number $11.08 \times 10^{3}$, equivalence ratio 1.27 , and pressure $1 \mathrm{bar}$.

reaction, and radical concentrations. In contrast, at holes diameter $2 \mathrm{~mm}$ effect of holes diameter on gas flow velocity is greater than effects of flame temperature and this is due to flame blow-off effect. Also the changes of holes diameter have no effect on $\mathrm{N}_{2}$ because equivalence ratio is kept constant. From our discussion, the optimum holes diameter for present work is $2.9 \mathrm{~mm}$ which corresponds to 0.68 as solidity ratio.

\subsection{Effect of Inlet Mixture Temperature on Combustion Process.} Effects of inlet mixture temperature on combustion process for light diesel and kerosene-air flames at residence time $7 \mathrm{~ms}$ are shown in Figure 10. Concentration, gas flow velocity, and flame temperature are measured for many runs to determine the range of inlet mixture temperature from point of complete evaporation to avoid condensation of fuel in mixing tube to maximum allowable inlet mixture temperature which affects flame stability where overheating of mixture and preflame reactions will reduce burning velocity. The main effect of inlet mixture temperature is for flame temperature and gas flow velocity. Due to the fact that all operating parameters are kept constant at burner tip except inlet mixture temperature so gas flow velocity increases due to increasing inlet temperature. Also effect of inlet mixture temperature on gas flow velocity for lean mixture is greater than for rich mixture and this effect decreases gradually with increased inlet mixture temperature. $\mathrm{CO}$ and $\mathrm{H}_{2}$ increase with increased inlet mixture temperature to 570 and $670 \mathrm{~K}$ for kerosene and light diesel-air flames, respectively. After that, $\mathrm{CO}$ and $\mathrm{H}_{2}$ are kept constant due 


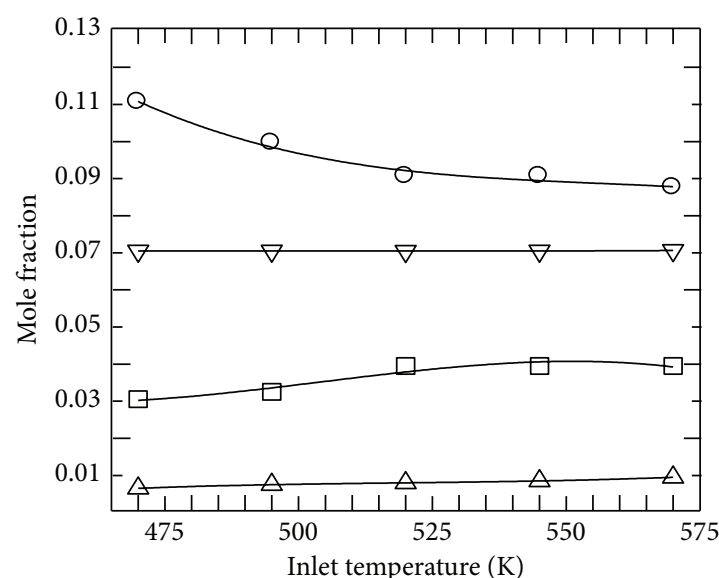

$\mathrm{O} \mathrm{CO}_{2}$ $\nabla \mathrm{N}_{2} \times 0.1$

$\square \mathrm{H}_{2}$

$\triangle \mathrm{CO}$

(a)

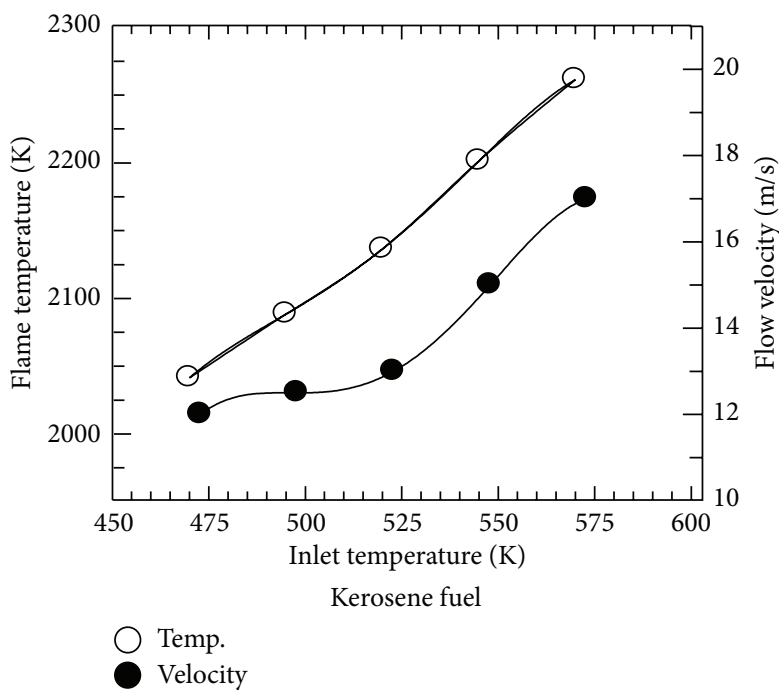

(c)

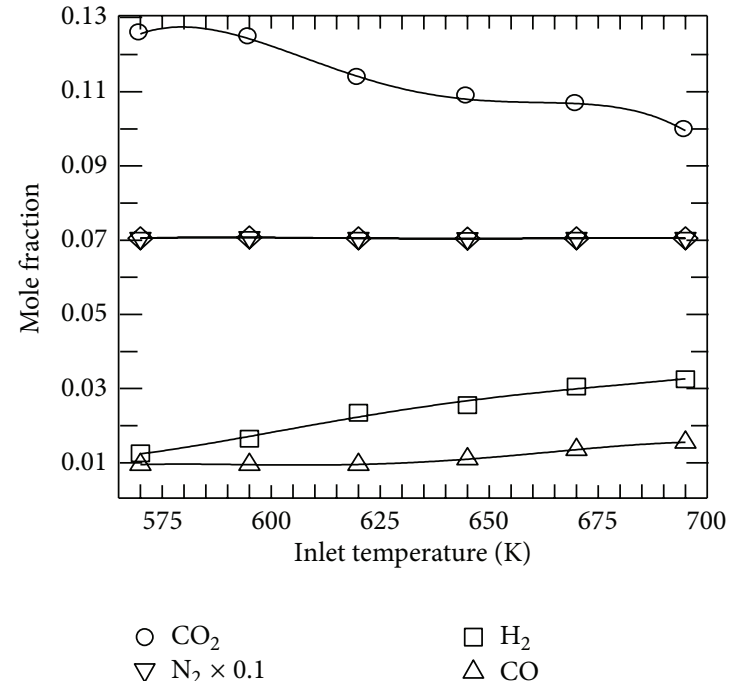

(b)

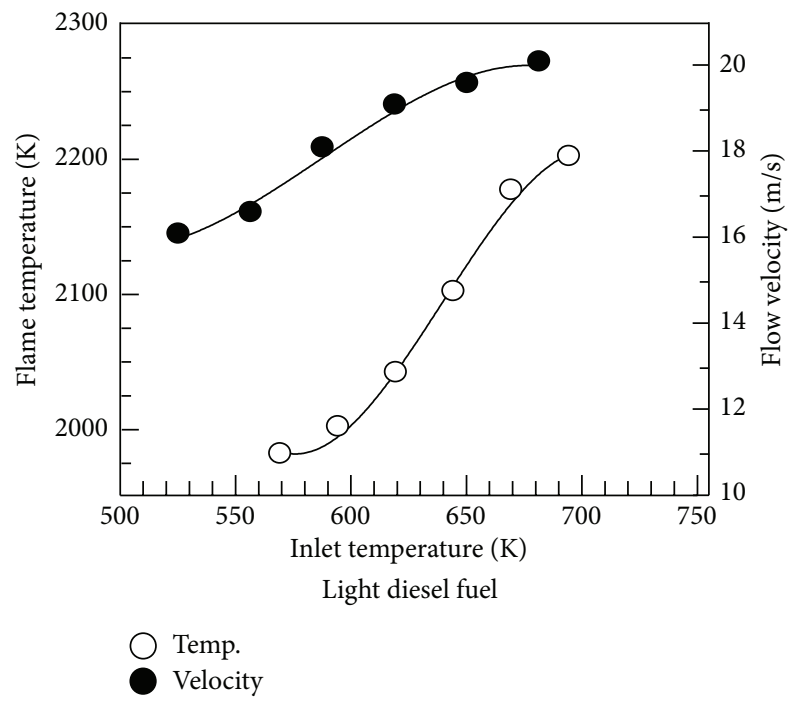

(d)

FIGURE 10: Effect of inlet temperature on flame structure for turbulent premixed air flame at residence time 7 ms, Reynolds number $11.08 \times 10^{3}$, solidity ratio 0.68 , equivalence ratio 1.13 , and pressure 1 bar.

to dissociation effect and decrease in burning velocity. So, formation rate of $\mathrm{CO}_{2}$ decreases with high rate after 570 and $670 \mathrm{~K}$ for both kerosene and light diesel-air flames. Effect of inlet mixture temperature on $\mathrm{N}_{2}$ is not appeared. For rich flames, effect of inlet mixture temperature on combustion process is high in main reaction zone and decreases gradually to end of flame. $\mathrm{CO}_{2}$ concentration decreases with increased inlet mixture temperature due to increasing dissociation where air mass flow rate holds constant. Inlet flow velocity increases with increased inlet temperature due to increase in specific volume of mixture. As inlet mixture temperature increases residence time of the min reaction zone decreases and complete combustion occurs in postflame zone. Flame temperature increases as inlet mixture temperature increases especially in pyrolysis zone due to incomplete combustion. So, rate of reaction of intermediate species, $\mathrm{CO}$ and $\mathrm{H}_{2}$, increases due to fuel pyrolysis. CO concentration decreases with increased inlet mixture temperature due to increase in flame temperature which accelerates conversion rate of $\mathrm{CO}$ to $\mathrm{CO}_{2}$. At stoichiometric and rich mixtures, high flame temperature promotes $\mathrm{CO}$ formation by dissociation. $\mathrm{CO}$ concentration increases as inlet mixture temperature increases.

\section{Conclusions}

(1) The main operating parameters as fuel type, fuel blends, equivalence ratio, Reynolds number, inlet mixture temperature, and design parameters as perforated plate holes diameter are major factors affecting combustion process for turbulent prevaporized premixed air flames. 
(2) $\mathrm{C}_{2} \mathrm{H}_{4}, \mathrm{C}_{2} \mathrm{H}_{6}$, and $\mathrm{C}_{3} \mathrm{H}_{8}$ concentrations for light diesel-air flame are higher than for kerosene-air flame while formation and dissipation rates of $\mathrm{C}_{2} \mathrm{H}_{4}, \mathrm{C}_{2} \mathrm{H}_{6}$, and $\mathrm{C}_{3} \mathrm{H}_{8}$ for kerosene-air flame are higher than for light diesel-air flame. Kerosene-air flames have flame temperature higher than light diesel-air flames.

(3) Light diesel-air flame is more stable under high flame temperature than kerosene-air flame due to high $\mathrm{C} / \mathrm{H}$ ratio.

(4) Effects of kerosene percentage for lean and rich flames are not linearly dependent for concentration, flame temperature, and gas flow velocity. Flame temperature and flow velocity increase with increased kerosene percentage in the blends. As light diesel percentage increases in the blends, decreasing rate of flame temperature and flow velocity for lean flame are higher than for rich flame especially in the postflame zone.

(5) Effect of equivalence ratio on the maximum flame temperature for rich flame is greater than for lean flame. For lean flame, as equivalence ratio increases by $12 \%$, maximum flame temperature increases by $16 \%$. For rich flame, as equivalence ratio increases by $16 \%$, maximum flame temperature decreases by $35 \%$.

(6) As Reynolds number increases, mixing rate of burned and unburned gases increases which increase flame temperature and rate of reaction of different species. In main reaction zone, $\mathrm{CO}_{2}$ concentration decreases with increased Reynolds number, while $\mathrm{H}_{2}$ and $\mathrm{CO}$ concentrations increase with increased Reynolds number. Effect of Reynolds number on concentration for light diesel-air flame is greater than for keroseneair flames

(7) For light diesel-air flame, effect of Reynolds number on flame temperature is greater than for kerosene-air flame especially in the main reaction zone.

(8) In the main reaction zone, as Reynolds number increases by $24 \%$ (from $9.912 \times 10^{3}$ to $13.1 \times 10^{3}$ ) flame temperatures of light diesel, kerosene-air flames increase by 200 and $50 \mathrm{~K}(18 \%, 10 \%)$, respectively. In the postflame zone, flames temperatures of light diesel and kerosene-air flames increase by 220 and $180 \mathrm{~K}$, respectively, for the same increase of Reynolds number.

(9) Gas flow velocity and flame temperature are more influenced by holes diameter, where gas flow velocity and flame temperature are compatible with each other and nearly decrease with the same rate. The optimum holes diameter is $2.9 \mathrm{~mm}$ which corresponds to 0.68 as solidity ratio.

(10) Inlet mixture temperature mainly affects maximum flame temperature and elementary rate of reaction leads to increase in fuel burning rate. Effect of inlet mixture temperature on gas flow velocity for lean mixture is greater than for rich mixture and this effect decreases gradually with increased inlet mixture temperature.

\section{Conflict of Interests}

The authors declare that there is no conflict of interests regarding the publication of this paper.

\section{References}

[1] A. El Bakali, P. Dagaut, L. Pillier et al., "Experimental and modeling study of the oxidation of natural gas in a premixed flame, shock tube, and jet-stirred reactor," Combustion and Flame, vol. 137, no. 1-2, pp. 109-127, 2004.

[2] G. R. Papagiannakis and T. D. Hountals, "Experimental investigation concerning the effect of natural gas percentage on performance and emissions of a DI dual fuel diesel engine," Applied Thermal Engineering, vol. 23, no. 3, pp. 353-365, 2003.

[3] A. S. El-Sherif, "Effects of natural gas composition on the nitrogen oxide, flame structure and burning velocity under laminar premixed flame conditions," Fuel, vol. 77, no. 14, pp. 1539-1547, 1998.

[4] Y. Tan, P. Dagaut, M. Cathonnet, and C. J. Boettner, "Natural gas and blends oxidation and ignition: experiments and modeling," Proceedings of the Combustion Institute, vol. 25, pp. 1563-1569, 1963.

[5] Y. Chen and M. Ihme, "Flame characterization of a piloted premixed jet burner," in Proceedings of the Spring Technical Meeting of the Central States Section of the Combustion Institute, pp. 2224, April 2012.

[6] R. Sadanandan, R. Lückerath, W. Meier, and C. Wahl, "Flame characteristics and emissions in flameless combustion under gas turbine relevant conditions," Journal of Propulsion and Power, vol. 27, no. 5, pp. 970-980, 2011.

[7] O. Obodeh and O. F. Isaac, "Investigation of performance characteristics of Diesel Engine Fueled with Diesel-Kerosene blends," Journal of Emerging Trends in Engineering and Applied Sciences, vol. 2, no. 2, pp. 318-322, 2011.

[8] T. K. Ghormade and N. V. Deshpande, "Soybean oil as an alternative fuels for I. C. engines," in Proceedings of the Recent Trends in Automotive Fuels, Nagpur, India, 2002.

[9] K. V. Kumar Reddy, Experimental investigations on the use of vegetable oil fuels in a 4-stroke single cylinder diesel engine [Ph.D. thesis], JNTU, Anantapur, India, 2000.

[10] K. A. Azad, M. S. Ameer Uddin, and M. M. Alam, "Experimental study of DI diesel engine performance using biodiesel blends with kerosene," International Journal of Energy and Environment, vol. 4, no. 2, pp. 265-278, 2013.

[11] S. Poovannan and G. Kalivarathan, "Performance evaluation of lean premixed prevapourised combustion chamber," International Journal of Mechanical Engineering and Technology, vol. 4, no. 2, pp. 127-133, 2013.

[12] S. R. Gollahalli, N. Dhamale, and R. N. Parthasarathy, "Effects of turbulence on the combustion properties of partially premixed flames of canola methyl ester and diesel blends," Journal of Combustion, vol. 2011, Article ID 697805, 13 pages, 2011.

[13] M. M. El Kotb, H. Salem, and S. M. Shehata, "Effect of flame stabilizer geometry on emissions of turbulent premixed blended flames," Experimental Thermal and Fluid Science, vol. 27, no. 4, pp. 343-353, 2003.

[14] N. M. Howe Jr., C. W. Shipman, and A. Vranos, "Turbulent mass transfer and rates of combustion in confined turbulent flames," Symposium (International) on Combustion, vol. 9, no. 1, pp. 3647, 1963. 
[15] R. Akrich, C. Vovelle, and R. Delbourgo, "Flame profiles and combustion mechanisms of methanol-air flames under reduced pressure," Combustion and Flame, vol. 32, pp. 171-179, 1978.

[16] C. K. Westbrook and F. L. Dryer, "Prediction of laminar flame properties of methanol-air mixtures," Combustion and Flame, vol. 37, pp. 171-192, 1980.

[17] K. Radhakrishnan, J. B. Heywood, and R. J. Tabaczynski, "Premixed turbulent flame blowoff velocity correlation based on coherent structures in turbulent flows," Combustion and Flame, vol. 42, pp. 19-33, 1981. 

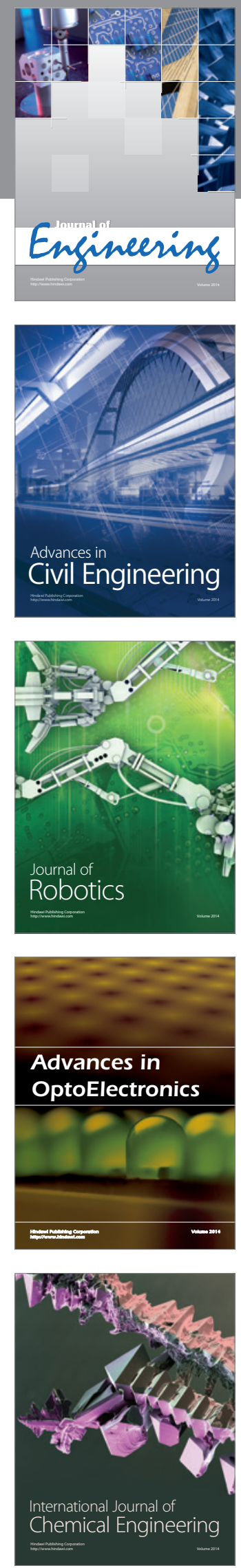

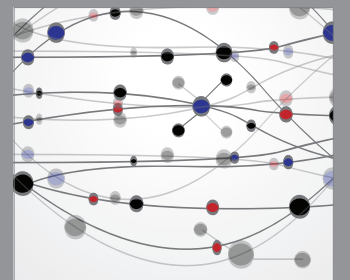

The Scientific World Journal
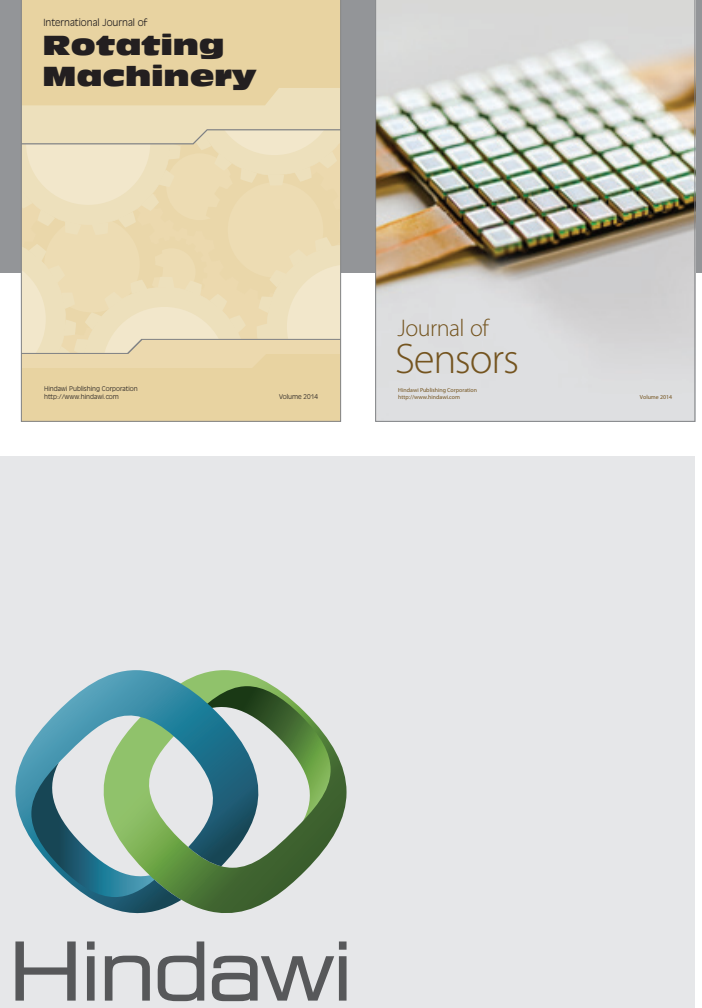

Submit your manuscripts at http://www.hindawi.com
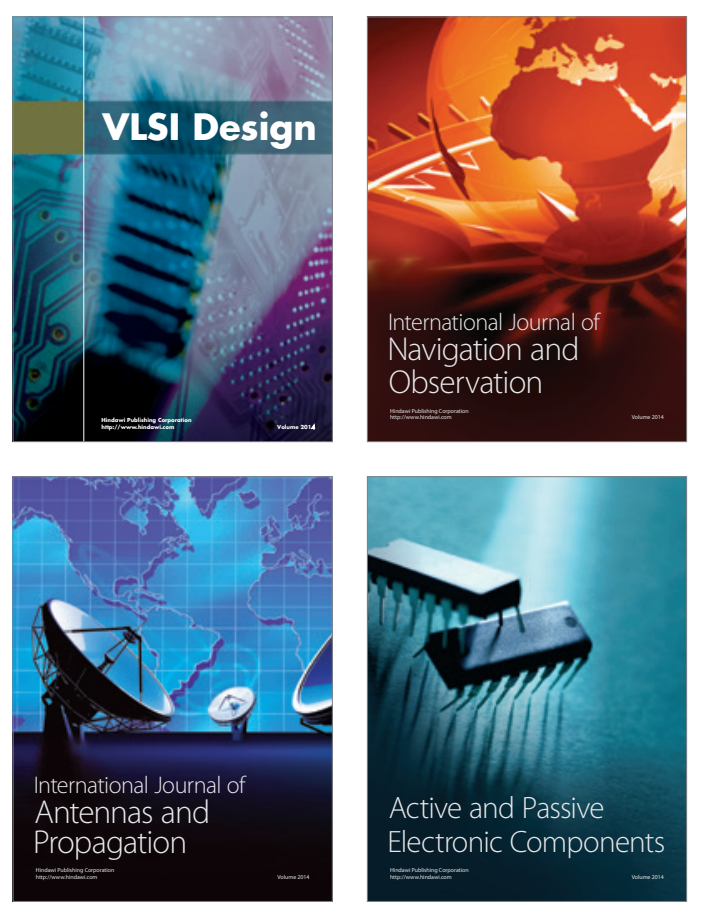
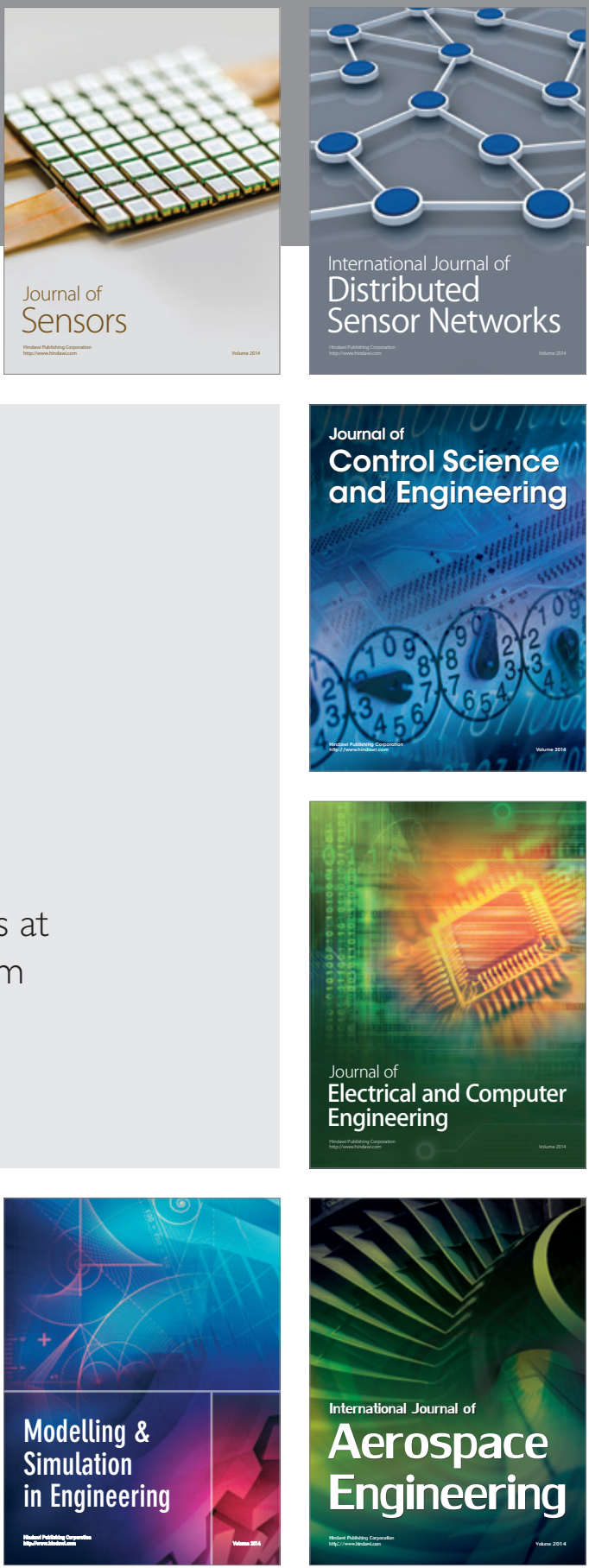

Journal of

Control Science

and Engineering
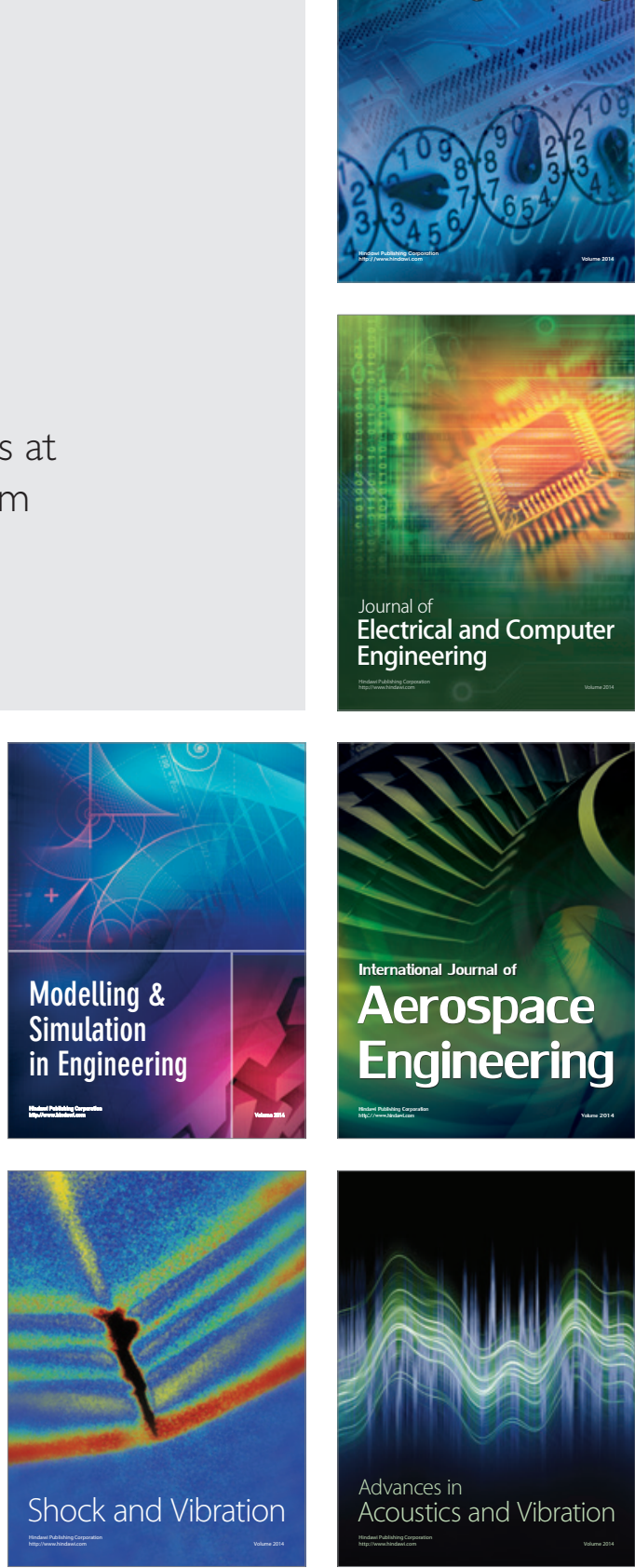